Atmos. Chem. Phys., 17, 11819-11833, 2017

https://doi.org/10.5194/acp-17-11819-2017

(c) Author(s) 2017. This work is distributed under

the Creative Commons Attribution 3.0 License.

\title{
Light-induced protein nitration and degradation with HONO emission
}

\author{
Hannah Meusel ${ }^{1}$, Yasin Elshorbany ${ }^{2,8}$, Uwe Kuhn ${ }^{1}$, Thorsten Bartels-Rausch ${ }^{3}$, Kathrin Reinmuth-Selzle ${ }^{1}$, \\ Christopher J. Kampf ${ }^{4}$, Guo Li ${ }^{1}$, Xiaoxiang Wang ${ }^{1}$, Jos Lelieveld ${ }^{5}$, Ulrich Pöschl ${ }^{1}$, Thorsten Hoffmann ${ }^{6}$, Hang Su $^{7,1}$, \\ Markus Ammann ${ }^{3}$, and Yafang Cheng ${ }^{1,7}$ \\ ${ }^{1}$ Max Planck Institute for Chemistry, Multiphase Chemistry Department, Mainz, Germany \\ ${ }^{2}$ NASA Goddard Space Flight Center, Greenbelt, Maryland, USA \\ ${ }^{3}$ Paul Scherrer Institute, Villigen, Switzerland \\ ${ }^{4}$ Johannes Gutenberg University of Mainz, Institute for Organic Chemistry, Mainz, Germany \\ ${ }^{5}$ Max Planck Institute for Chemistry, Atmospheric Chemistry Department, Mainz, Germany \\ ${ }^{6}$ Johannes Gutenberg University of Mainz, Institute for Inorganic and Analytical Chemistry, Mainz, Germany \\ ${ }^{7}$ Institute for Environmental and Climate Research, Jinan University, Guangzhou, China \\ ${ }^{8}$ Earth System Science Interdisciplinary Center, University of Maryland, College Park, Maryland, USA
}

Correspondence to: Y. Cheng (yafang.cheng@mpic.de) and H. Su (h.su@ mpic.de)

Received: 24 March 2017 - Discussion started: 28 March 2017

Revised: 9 August 2017 - Accepted: 3 September 2017 - Published: 6 October 2017

\begin{abstract}
Proteins can be nitrated by air pollutants $\left(\mathrm{NO}_{2}\right)$, enhancing their allergenic potential. This work provides insight into protein nitration and subsequent decomposition in the presence of solar radiation. We also investigated lightinduced formation of nitrous acid (HONO) from protein surfaces that were nitrated either online with instantaneous gas-phase exposure to $\mathrm{NO}_{2}$ or offline by an efficient nitration agent (tetranitromethane, TNM). Bovine serum albumin (BSA) and ovalbumin (OVA) were used as model substances for proteins. Nitration degrees of about $1 \%$ were derived applying $\mathrm{NO}_{2}$ concentrations of $100 \mathrm{ppb}$ under VIS/UV illuminated conditions, while simultaneous decomposition of (nitrated) proteins was also found during long-term $(20 \mathrm{~h})$ irradiation exposure. Measurements of gas exchange on TNMnitrated proteins revealed that HONO can be formed and released even without contribution of instantaneous heterogeneous $\mathrm{NO}_{2}$ conversion. $\mathrm{NO}_{2}$ exposure was found to increase HONO emissions substantially. In particular, a strong dependence of HONO emissions on light intensity, relative humidity, $\mathrm{NO}_{2}$ concentrations and the applied coating thickness was found. The $20 \mathrm{~h}$ long-term studies revealed sustained HONO formation, even when concentrations of the intact (nitrated) proteins were too low to be detected after the gas
\end{abstract}

exchange measurements. A reaction mechanism for the $\mathrm{NO}_{2}$ conversion based on the Langmuir-Hinshelwood kinetics is proposed.

\section{Introduction}

Primary biological aerosols, or bioaerosols, including proteins, from different sources and with distinct properties are known to influence atmospheric cloud microphysics and public health (Lang-Yona et al., 2016; D'Amato et al., 2007; Pummer et al., 2015). Bioaerosols represent a diverse subset of atmospheric particulate matter that is directly emitted in form of active or dead organisms, or fragments, like bacteria, fungal spores, pollens, viruses and plant debris. Proteins are found ubiquitously in the atmosphere as part of these airborne, typically coarse-sized biological particles (diameter $>2.5 \mu \mathrm{m}$ ), as well as in fine particulate matter (diameter $<2.5 \mu \mathrm{m}$ ) associated with a host of different constituents such as polymers derived from biomaterials and proteins dissolved in hydrometeors, mixed with fine dust and other particles (Miguel et al., 1999; Riediker et al., 2000; Zhang and Anastasio, 2003). Proteins contribute up to $5 \%$ of par- 


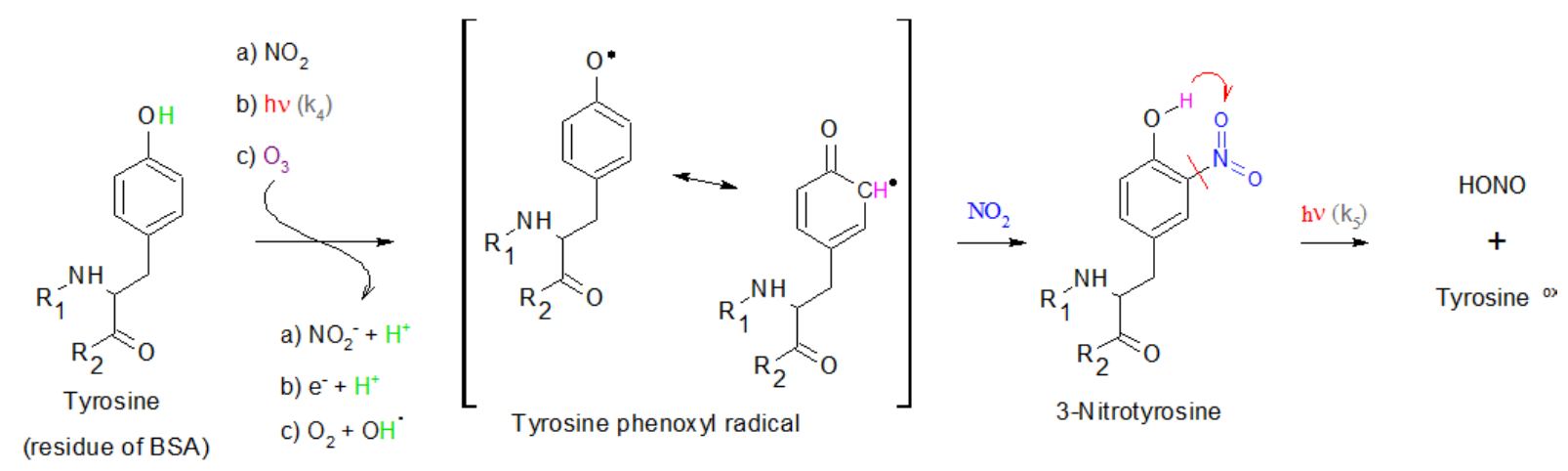

Figure 1. Overview on possible reaction mechanisms of atmospheric BSA nitration and subsequent HONO emission. The tyrosine phenoxyl radical intermediate is formed by the reaction of tyrosine with either (a) $\mathrm{NO}_{2}$, (b) light or (c) ozone. A second reaction with $\mathrm{NO}_{2}$ forms 3 nitrotyrosine (adapted from Houée-Levin et al., 2015, and Shiraiwa et al., 2012). Subsequent intramolecular H transfer initiated by irradiation decompose the protein and HONO is emitted (adapted from Bejan et al., 2006).

ticle mass in airborne particles (Franze et al., 2003a; Staton et al., 2015; Menetrez et al., 2007) and are also found at surfaces of soils and plants. Proteins can be nitrated and are then likely to enhance allergic responses (Gruijthuijsen et al., 2006). Nitrogen dioxide $\left({ }^{\circ} \mathrm{NO}_{2}\right)$ has emerged as an important biological reactant and has been shown to be capable of electron (or $\mathrm{H}$ atom) abstraction from the amino acid tyrosine (Tyr) to form $\mathrm{TyrO}^{\bullet}$ in aqueous solutions (tyrosine phenoxyl radical, also called tyrosyl radical; Prütz et al., 1984, 1985; Alfassi, 1987; Houée-Lévin et al., 2015), which subsequently can be nitrated by a second $\mathrm{NO}_{2}$ molecule. Shiraiwa et al. (2012) observed nitration of protein aerosol, but not solely with $\mathrm{NO}_{2}$ in the gas phase, and demonstrated that simultaneous $\mathrm{O}_{3}$ exposure of airborne proteins in dark conditions can significantly enhance $\mathrm{NO}_{2}$ uptake and consequent protein nitration (3-nitrotyrosine formation) by way of direct $\mathrm{O}_{3}$ mediated formation of the $\mathrm{TyrO}^{\bullet}$ intermediate. A connection between increased allergic diseases and elevated environmental pollution, especially traffic-related air pollution has been proposed (Ring et al., 2001). Tyrosine is one of the photosensitive amino acids and it is subject of direct and indirect photo-degradation under solar-simulated conditions (Boreen et al., 2008), especially mediated by both UV-B ( $\lambda$ $280-320 \mathrm{~nm})$ and UV-A $(\lambda 320-400 \mathrm{~nm})$ radiation (HoueeLevin et al., 2015; Bensasson et al., 1993). Direct light absorption or absorption by adjacent endogenous or exogenous chromophores and subsequent energy transfer results in an electronically excited state of tyrosine (for details see HouéeLévin et al., 2015, and references therein). If the triplet state of tyrosine is generated, it can undergo electron transfer reactions and deprotonation to yield $\mathrm{TyrO}^{*}$ (Fig. 1; Bensasson, 1993; Davies, 1991; Berto et al., 2016). Regardless of how the tyrosyl radical is generated, it can be nitrated by reaction with $\mathrm{NO}_{2}$, as well as hydroxylated or dimerized (Shiraiwa et al., 2012; Reinmuth-Selzle et al., 2014; Kampf et al., 2015).
With respect to atmospheric chemistry, Bejan et al. (2006) have shown that photolysis of ortho-nitrophenols (as is the case for 3-nitrotyrosine) can generate nitrous acid (HONO). $\mathrm{HONO}$ is of great interest for atmospheric composition, as its photolysis forms $\mathrm{OH}$ radicals, which are the key oxidant for degradation of most air pollutants in the troposphere (Levy, 1971). In the lower atmosphere, up to $30 \%$ of the primary $\mathrm{OH}$ radical production can be attributed to photolysis of HONO, especially during the early morning when other photochemical OH sources are still small (Reaction R1, Kleffmann et al., 2005; Alicke et al., 2002; Ren et al., 2006; Su et al., 2008; Meusel et al., 2016).

$\mathrm{HONO} \stackrel{h v}{\longrightarrow} \mathrm{OH}+\mathrm{NO} \quad(h v=300-405 \mathrm{~nm})$

HONO can be directly emitted by combustion of fossil fuels (Kurtenbach et al., 2001) or formed by gas-phase reactions of $\mathrm{NO}$ and $\mathrm{OH}$ (the backwards reaction of Reaction $\mathrm{R} 1$ ) and heterogeneous reactions of $\mathrm{NO}_{2}$ on wet surfaces according to Reaction (R2). On carbonaceous surfaces (soot, phenolic compounds) $\mathrm{HONO}$ is formed via electron or $\mathrm{H}$ transfer reactions (Reactions R3 and R4-R6; Kalberer et al., 1999; Kleffmann et al., 1999; Gutzwiller et al., 2002; Aubin and Abbatt, 2007; Han et al., 2013; Arens et al., 2001, 2002; Ammann et al., 1998, 2005).

$$
\begin{aligned}
& 2 \mathrm{NO}_{2}+\mathrm{H}_{2} \mathrm{O} \rightarrow \mathrm{HONO}+\mathrm{HNO}_{3} \\
& \mathrm{NO}_{2}+\{\mathrm{C}-\mathrm{H}\}_{\mathrm{red}} \rightarrow \mathrm{HONO}+\{\mathrm{C}\}_{\mathrm{ox}} \\
& \mathrm{ArOH}+\mathrm{NO}_{2} \rightarrow \mathrm{ArO}+\mathrm{HONO} \\
& \mathrm{ArOH}+\mathrm{H}_{2} \mathrm{O} \rightarrow \mathrm{ArO}^{-}+\mathrm{H}_{3} \mathrm{O}^{+} \\
& \mathrm{ArO}^{-}+\mathrm{NO}_{2} \rightarrow \mathrm{NO}_{2}^{-}+\mathrm{ArO}^{\cdot} \stackrel{\mathrm{H}_{3} \mathrm{O}^{+}}{\longrightarrow} \mathrm{HONO}+\mathrm{H}_{2} \mathrm{O}
\end{aligned}
$$

Previous atmospheric measurements and modeling studies have shown unexpected high HONO concentrations during daytime, which can also contribute to aerosol formation through enhanced oxidation of precursor gases (Elshorbany et al., 2014). Measured mixing ratios are typically about 1 
order of magnitude higher than simulated ones, and an additional source of $200-800 \mathrm{ppth}^{-1}$ would be required to explain observed mixing ratios (Kleffmann et al., 2005; Acker et al., 2006; Sörgel et al., 2011; Li et al., 2012; Su et al., 2008; Elshorbany et al., 2012; Meusel et al., 2016), indicating that estimates of daytime HONO sources are still under debate. It was suggested that HONO arises from the photolysis of nitric acid and nitrate or by heterogeneous photochemistry of $\mathrm{NO}_{2}$ on organic substrates and soot (Zhou et al., 2001, 2002 and 2003; Villena et al., 2011; Ramazan et al., 2004; George et al., 2005; Sosedova et al., 2011; Monge et al., 2010; Han et al., 2016). Stemmler et al. (2006, 2007) found HONO formation on light-activated humic acid, and field studies showed that HONO formation correlates with aerosol surface area, $\mathrm{NO}_{2}$ and solar radiation (Su et al., 2008; Reisinger, 2000; Costabile et al., 2010; Wong et al., 2012; Sörgel et al., 2015) and is increased during foggy periods (Notholt et al., 1992). Another proposed source of HONO is the soil, where it has been found to be co-emitted with $\mathrm{NO}$ by soil biological activities (Oswald et al., 2013; Su et al., 2011; Weber et al., 2015).

In view of light-induced nitration of proteins and HONO formation by photolysis of nitrophenols, light-enhanced production of HONO on protein surfaces can be anticipated, which, to the best of our knowledge, has not been studied before.

This work aims to provide insight into protein nitration, the atmospheric stability of the nitrated protein and respective formation of HONO from protein surfaces that were nitrated either offline in liquid phase prior to the gas exchange measurements or online with instantaneous gas-phase exposure to $\mathrm{NO}_{2}$, with particular emphasis on environmental parameters like light intensity, relative humidity $(\mathrm{RH})$ and $\mathrm{NO}_{2}$ concentrations. Bovine serum albumin (BSA), a globular protein with a molecular mass of $66.5 \mathrm{kDa}$ and 21 tyrosine residues per molecule, was chosen as a well-defined model substance for proteins. Nitrated ovalbumin (OVA) was used to study the light-induced degradation of proteins that were nitrated prior to gas exchange measurements. This wellstudied protein has a molecular mass of $45 \mathrm{kDa}$ and 10 tyrosine residues per molecule.

\section{Materials and methods}

\subsection{Protein preparation and analysis}

BSA (Cohn V fraction, lyophilized powder, $\geq 96 \%$; Sigma Aldrich, St. Louis, Missouri, USA) or nitrated OVA was solved in pure water $(18.2 \mathrm{M} \Omega \mathrm{cm})$ and coated onto the glass tube.

The nitration of OVA was described previously (Yang et al., 2010; Zhang et al., 2011). Briefly, OVA (grade V, A5503-5G, Sigma Aldrich, Germany) was dissolved in phosphate-buffered saline PBS (P4417-50TAB, Sigma
Aldrich, Germany) to a concentration of $10 \mathrm{mg} \mathrm{ml}^{-1} .50 \mu \mathrm{L}$ tetranitromethane (TNM; T25003-5G, Sigma Aldrich, Germany) dissolved in methanol $4 \%(v / v)$ were added to a $2.5 \mathrm{~mL}$ aliquot of the OVA solution and stirred for $180 \mathrm{~min}$ at room temperature. Please note that TNM is toxic if swallowed, can cause skin, eye and respiration irritation, is suspected to cause cancer and causes fires or explosions. Size exclusion chromatography columns (PD-10 Sephadex G25 M, 17-0851-01, GE Healthcare, Germany) were used for cleanup. The eluate was dried in a freeze dryer and stored in a refrigerator at $4{ }^{\circ} \mathrm{C}$.

After the flow-tube experiments (see below) the proteins were extracted with water from the tube and analyzed with liquid chromatography (HPLC-DAD; Agilent Technologies 1200 series) according to Selzle et al. (2013). This method provides a straightforward and efficient way to determine the nitration of proteins. Briefly, a monomerically bound C18 column (Vydac 238TP, $250 \mathrm{~mm} \times 2.1 \mathrm{~mm}$ inner diameter, $5 \mu \mathrm{m}$ particle size; Grace Vydac, Alltech) was used for chromatographic separation. Eluents were $0.1 \%(v / v)$ trifluoroacetic acid in water (LiChrosolv) (eluent $\mathrm{A}$ ) and acetonitrile (ROTISOLV HPLC gradient grade, Carl Roth $\mathrm{GmbH}$ + Co. KG, Germany) (eluent B). Gradient elution was performed at a flow rate of $200 \mu \mathrm{L} \mathrm{min}^{-1}$. ChemStation software (Rev. B.03.01, Agilent) was used for system control and data analysis. For each chromatographic run, the solvent gradient started at $3 \% \mathrm{~B}$ followed by a linear gradient to $90 \% \mathrm{~B}$ within $15 \mathrm{~min}$, flushing back to $3 \% \mathrm{~B}$ within $0.2 \mathrm{~min}$ and maintaining $3 \% \mathrm{~B}$ for additional $2.8 \mathrm{~min}$. Column reequilibration time was $5 \mathrm{~min}$ before the next run. Absorbance was monitored at wavelengths of 280 (tyrosine) and $357 \mathrm{~nm}$ (nitrotyrosine). The sample injection volume was $10-30 \mu \mathrm{L}$. Each chromatographic run was repeated three times. The protein nitration degree (ND), which is defined as the ratio of nitrated tyrosine to all tyrosine residues, was determined by the method of Selzle et al. (2013). Native and untreated BSA did not show any degree of nitration.

\subsection{Coated-wall flow tube system}

Figure 2 shows a flowchart of the setup of the experiment. $\mathrm{NO}_{2}$ was provided in a gas bottle (1 ppm in $\mathrm{N}_{2}$, Carbagas $\mathrm{AG}$, Grümligen, Switzerland). $\mathrm{NO}_{2}$ was further diluted (mass flow controller, MFC3) with humidified pure nitrogen to achieve $\mathrm{NO}_{2}$ mixing ratios between 20 and $100 \mathrm{ppb}$. Impurities of $\mathrm{HONO}$ in the $\mathrm{NO}_{2}$-gas cylinder were removed by means of a $\mathrm{HONO}$ scrubber. The $\mathrm{Na}_{2} \mathrm{CO}_{3}$ trap was prepared by soaking $4 \mathrm{~mm}$ firebrick in a saturated $\mathrm{Na}_{2} \mathrm{CO}_{3}$ in $50 \%$ ethanol-water solution and drying for $24 \mathrm{~h}$. The impregnated firebrick granules were put into a $0.8 \mathrm{~cm}$ inner diameter and $15 \mathrm{~cm}$ long glass tube, which was closed by quartz wool plugs on both sides. A constant total flow $\left(1400 \mathrm{~mL} \mathrm{~min}^{-1}\right)$ was provided by means of another $\mathrm{N}_{2}$ mass flow controller (MFC2) that compensated for changes in $\mathrm{NO}_{2}$ addition. Different fractions of total surface areas $(50,70$ and $100 \%)$ of 
Table 1. Details on the different experiments, aims and experimental conditions (coating, applied $\mathrm{NO}_{2}$ concentration, number of lights switched on, relative humidity and time for each exposure step).

\begin{tabular}{|c|c|c|c|c|c|c|}
\hline & & 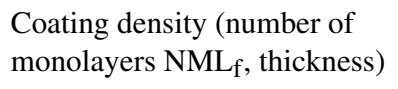 & $\begin{array}{r}\mathrm{NO}_{2} \\
(\mathrm{ppb})\end{array}$ & No. of lamps & $\begin{array}{l}\mathrm{RH} \\
(\%)\end{array}$ & $\begin{array}{r}\text { Time per step } \\
\text { (h) }\end{array}$ \\
\hline \multicolumn{7}{|c|}{ (a) Light-induced decomposition of nitrated protein and HONO formation } \\
\hline 1 & $\begin{array}{l}\text { Light and } \mathrm{NO}_{2} \\
\text { dependency }\end{array}$ & $\begin{array}{l}n \text {-OVA } 21.5 \pm 0.8 \mu \mathrm{g} \mathrm{cm}^{-2} \\
\left(68 \mathrm{NML}_{\mathrm{f}}, 298.05 \mathrm{~nm}\right)\end{array}$ & $0-20$ & 0-1-3-7 VIS & 50 & 1 \\
\hline \multicolumn{7}{|c|}{ (b) Heterogeneous $\mathrm{NO}_{2}$ transformation on BSA } \\
\hline 2 & $\mathrm{NO}_{2}$ dependency & $\begin{array}{l}\text { BSA } 16.1 \pm 0.4 \mu \mathrm{g} \mathrm{cm}^{-2} \\
\left(50 \mathrm{NML}_{\mathrm{f}}, 217.6 \mathrm{~nm}\right)\end{array}$ & $0-20-40-60-100$ & 7 VIS & 50 & $0.5-1$ \\
\hline 3 & Light dependency & $\begin{array}{l}\text { BSA } 31.4 \pm 1.4 \mu \mathrm{g} \mathrm{cm}^{-2} \\
\left(99 \mathrm{NML}_{\mathrm{f}}, 435.2 \mathrm{~nm}\right)\end{array}$ & 20 & $0-1-3-7$ VIS & 50 & $0.5-1$ \\
\hline 4 & Coating thickness & $\begin{array}{l}\text { BSA } 16.1 \pm 0.4 \mu \mathrm{g} \mathrm{cm}^{-2} \\
\left(50 \mathrm{NML}_{\mathrm{f}}, 217.6 \mathrm{~nm}\right) \\
22.5 \pm 0.8 \mu \mathrm{g} \mathrm{cm}^{-2} \\
\left(71 \mathrm{NML}_{\mathrm{f}}, 310.8 \mathrm{~nm}\right) \\
31.4 \pm 1.4 \mu \mathrm{g} \mathrm{cm}^{-2} \\
\left(99 \mathrm{NML}_{\mathrm{f}}, 435.2 \mathrm{~nm}\right)\end{array}$ & 20 & 7 VIS & & $0.5-3$ \\
\hline 5 & RH dependency & $\begin{array}{l}\text { BSA } 17.5 \pm 0.4 \mu \mathrm{g} \mathrm{cm}^{-2} \\
\left(55 \mathrm{NML}_{\mathrm{f}}, 241.7 \mathrm{~nm}\right)\end{array}$ & 25 & 0-7 VIS & $0-50-80$ & $0.25-1$ \\
\hline 6 & Time effect & BSA $17.5 \pm 0.4 \mu \mathrm{g} \mathrm{cm}^{-2}$ & 100 & $7 \mathrm{VIS}$ & 75 & 20 \\
\hline 7 & Time effect & BSA $17.5 \pm 0.4 \mu \mathrm{g} \mathrm{cm}^{-2}$ & 100 & $4 \mathrm{VIS}+3 \mathrm{UV}$ & 75 & 20 \\
\hline
\end{tabular}

$\mathrm{NML}_{\mathrm{f}}$ numbers of monolayers in flat orientation.

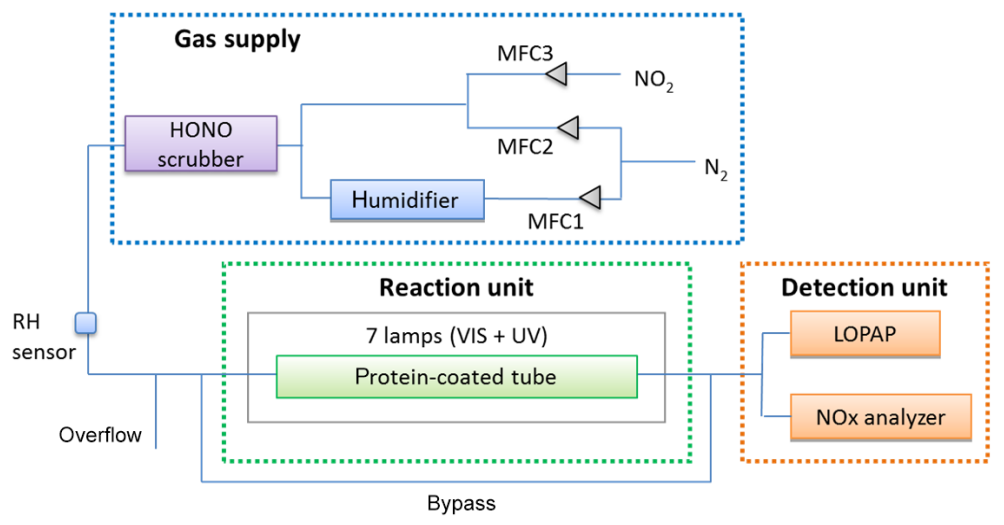

Figure 2. Flow system and setup: thin blue lines show the flow of the gas mixture, which direction is indicated by the grey triangles of the mass flow controllers (MFC). Nitrogen passes a heated water bath to humidify the gas and a HONO scrubber to eliminate any HONO impurities of the $\mathrm{NO}_{2}$ supply. The overflow maintains a constant pressure through the reaction tube and the detection unit. The dotted boxes (blue, green, orange) indicate the three different parts: the gas supply, reaction unit and detection unit.

the reaction tube $(50 \mathrm{~cm} \times 0.81 \mathrm{~cm}$ i.d.) were coated with $2 \mathrm{mg}$ BSA or nitrated OVA, respectively. Therefore $2 \mathrm{mg}$ protein was dissolved in $600 \mu \mathrm{L}$ pure water, injected into the tube and then gently dried in a low-humidity $\mathrm{N}_{2}$ flow $(\mathrm{RH} \sim 30-40 \%)$ with continuous rotation of the tube. The coated reaction tube was exposed to the generated gas mixture and irradiated with either (i) one, three or seven visible (VIS) lights (400-
$700 \mathrm{~nm}$; L $15 \mathrm{~W} / 954$, Lumilux de Luxe daylight, Osram, Augsburg, Germany), which is $0,23,69$ or $161 \mathrm{~W} \mathrm{~m}^{-2}$, respectively; or (ii) four VIS and three UV lights (340-400 nm; UV-A, TL-D 15 W/10, Philips, Hamburg, Germany).

An overview of the experiments performed during this study is shown in Table 1. Light-induced decomposition of nitrated proteins was studied on OVA. Instantaneous $\mathrm{NO}_{2}$ 
transformation and its light and RH dependence on heterogeneous HONO formation were studied on BSA in short-term experiments. Extended studies on BSA were performed to explore the persistence of the surface reactivity and respective catalytic effects.

A commercial long-path absorption photometry instrument (LOPAP, QUMA) was used for HONO analysis. The measurement technique was introduced by Heland et al. (2001). This wet chemical analytical method has an unmatched low detection limit of 3-5 ppt with high HONO collection efficiency ( $\geq 99 \%$ ). HONO is continuously trapped in a stripping coil flushed with an acidic solution of sulfanilamide. In a second reaction with n(1-naphthyl)ethylenediamine-dihydrochloride an azo dye is formed, whose concentration is determined by absorption photometry in a long Teflon tubing. LOPAP has two stripping coils in series to reduce known interferences. In the first stripping coil HONO is quantitatively collected. Due to the acidic stripping solution, interfering species are collected less efficiently but in both channels. The true concentration of HONO is obtained by subtracting the interferences quantified in the second channel from the total signal obtained in the first channel. The accuracy of the HONO measurements was $10 \%$, based on the uncertainties of liquid and gas flow, concentration of calibration standard and regression of calibration.

The reagents were all high-purity-grade chemicals, i.e., hydrochloric acid (37\%, ACS reagent, Sigma Aldrich, St. Louis, Missouri, USA), sulfanilamide (for analysis, > $99 \%$; Sigma Aldrich) and N-(1-naphthyl)-ethylenediamine dihydrochloride (> $98 \%$; ACS reagent, Fluka by Sigma Aldrich). For calibration Titrisol ${ }^{\circledR} 1000 \mathrm{mg} \mathrm{NO}_{2}^{-}\left(\mathrm{NaNO}_{2}\right.$ in $\mathrm{H}_{2} \mathrm{O}$; Merck) was diluted to $0.001 \mathrm{mg} \mathrm{L}^{-1} \mathrm{NO}_{2}^{-}$. For preparation of all solutions and for cleaning of the absorption tubes $18 \mathrm{M} \Omega$ $\mathrm{H}_{2} \mathrm{O}$ was used.

$\mathrm{NO}_{x}$ concentrations were analyzed by means of a commercial chemiluminescence detector from EcoPhysics (CLD 77 AM, Duernten, Switzerland).

\section{Results and discussion}

\subsection{BSA nitration and degradation}

Nitrated proteins can trigger allergic response. The nitration of proteins can be enhanced by $\mathrm{O}_{3}$ activation (in the dark). In the atmospheric environment, about half the time sunlight is present. What happens with irradiated proteins when exposed to $\mathrm{NO}_{2}$ ? Can they be nitrated efficiently? To investigate the degree of protein nitration under illuminated conditions, BSA coated on the reaction tube $\left(17.5 \mu \mathrm{g} \mathrm{cm}^{-2}\right)$ was exposed to seven VIS lamps (40\% of a clear-sky irradiance for a solar zenith of $48^{\circ}$; Stemmler et al., 2006) and $100 \mathrm{ppb}$ $\mathrm{NO}_{2}$ at $70 \% \mathrm{RH}$. After $20 \mathrm{~h}$ the BSA ND (concentration of nitrated tyrosine residues divided by the total concentration of tyrosine residues) investigated by means of the HPLCDAD method was $(1.0 \pm 0.1) \%$, significantly higher than the ND of untreated BSA $(0 \%)$. Introducing UV radiation (four VIS plus three UV lamps) resulted in a slightly higher ND of $(1.1 \pm 0.1) \%$. Note that no intact protein (nitrated and nonnitrated) could be detected by HPLC-DAD after another $20 \mathrm{~h}$ of irradiation without $\mathrm{NO}_{2}$, indicating light-induced decomposition of proteins. However, the applied HPLC-DAD technique only detects (nitro-)tyrosine residues in proteins and does not provide information about protein fragments or single nitrated or non-nitrated tyrosine residues. Hence, proteins might have been decomposed while tyrosine remains in its nitrated form, not detectable by our analysis method. Similarly, proteins (here OVA) that were nitrated with TNM in aqueous phase prior to coating $\left(21.5 \mu \mathrm{g} \mathrm{cm}^{-2}\right)$ to an extent of $12.5 \%$ also decomposed when illuminated about $6 \mathrm{~h}$ (one to seven VIS lights; with and without $20 \mathrm{ppb} \mathrm{NO}_{2}$ ). Thus the nitration of proteins by light and $\mathrm{NO}_{2}$ was confirmed, but with simultaneous gradual decomposition of the proteins. Effects of UV irradiation $(240-340 \mathrm{~nm})$ on proteins containing aromatic amino acids were reviewed previously (NevesPeterson et al., 2012). It was shown that triplet state tryptophan and tyrosine can transfer electron to a nearby disulfide bridge to form the tryptophan and tyrosine radical. The disulfide bridge could break leading to conformational changes in the protein but not necessarily resulting in inactivation of the protein. In strong UV light $(\approx 200 \mathrm{~nm})$ the peptide bond could also break (Nikogosyan and Görner, 1999).

Franze et al. (2005) analyzed a variety of natural samples (road dust, window dust and particulate matter $\mathrm{PM}_{2.5}$ ) collected in the metropolitan area of Munich, containing 0.08$21 \mathrm{~g} \mathrm{~kg}^{-1}$ proteins, and revealed equivalent degrees of nitration (EDN, concentration of nitrated protein divided by concentration of all proteins) between 0.01 and $0.1 \%$ only. Such low nitration degree is in line with light-induced decomposition of (nitrated) proteins. In contrast, an EDN up to $10 \%$ (average $5 \%$ ) was found for BSA and birch pollen extract exposed to Munich ambient air for 2 weeks under dark conditions, with daily mean $\mathrm{NO}_{2}\left(\mathrm{O}_{3}\right)$ concentration of $17-50 \mathrm{ppb}(7-43 \mathrm{ppb})$ in the same study, possibly suggesting the deficiency of decomposition without being irradiated. BSA and OVA loaded on syringe filters and exposed to $200 \mathrm{ppb} \mathrm{NO}_{2} / \mathrm{O}_{3}$ for 6 days under dark conditions were nitrated to 6 and $8 \%$, respectively (Yang et al., 2010). Reinmuth-Selzle et al. (2014) found similar ND for major birch pollen allergen Bet $\mathrm{v} 1$ loaded on syringe filters exposed to 80-470 ppb $\mathrm{NO}_{2}$ and $\mathrm{O}_{3}$. When exposed for 3-72 $\mathrm{h}$ to $\mathrm{NO}_{2} / \mathrm{O}_{3}$ at $\mathrm{RH}<92 \%$ the ND was $2-4 \%$, while at condensing conditions $(\mathrm{RH}>98 \%)$ the ND increased to $6 \%$ after less than 1 day $(19 \mathrm{~h})$. The ND of Bet $\mathrm{v} 1$ was considerably increased to $22 \%$ for proteins solved in the aqueous phase $\left(0.16 \mathrm{mg} \mathrm{mL}^{-1}\right)$ when bubbling with a $120 \mathrm{ppb}$ $\mathrm{NO}_{2} / \mathrm{O}_{3}$ gas mixture for a similar period of time $(17 \mathrm{~h})$. Shiraiwa et al. (2012) performed kinetic modeling and found that maximum $30 \%$ (conservative upper limit) of $\mathrm{N}$ uptake 
on BSA could be explained by $\mathrm{NO}_{3}$ or $\mathrm{N}_{2} \mathrm{O}_{5}$, which are generated by the reaction of $\mathrm{NO}_{2}$ and $\mathrm{O}_{3}$, while overall nitration was governed by an indirect mechanism in which a radical intermediate was formed by the reaction of BSA with ozone, which then reacted with $\mathrm{NO}_{2}$. On $\mathrm{NaCl}$ surface $\mathrm{N}$ uptake was dominated by $\mathrm{NO}_{3}$ and $\mathrm{N}_{2} \mathrm{O}_{5}$. Furthermore, $\mathrm{NO}_{3}$ radicals, which in this study could be formed by photolysis of $\mathrm{NO}_{2}$ (> $410 \mathrm{~nm}$, disproportionation of excited $\mathrm{NO}_{2}$ ), are not stable under the light conditions applied (400-700 nm) (Johnston et al., 1996). Therefore, in the present study reactions with $\mathrm{NO}_{3}$ were neglected. Photolysis of $\mathrm{NO}_{2}$ forming NO $(<400 \mathrm{~nm})$ can also be neglected (Gardner et al., 1987; Roehl et al., 1994). A photolysis frequency for $\mathrm{NO}_{2}$ of up to $5 \times 10^{-4} \mathrm{~s}^{-1}$ under similar experimental light conditions was determined by Stemmler et al., 2007. Other nitration methods investigated by Reinmuth-Selzle et al. (2014), e.g., nitration of Bet $\mathrm{v} 1$ with peroxynitrite $\left(\mathrm{ONOO}^{-}\right.$, formed by reaction of $\mathrm{NO}$ with $\mathrm{O}_{2}^{-}$) or TNM, lead to ND between 10 and $72 \%$ depending on reaction time, reagent concentration and temperature. Similarly, high NDs of $45-50 \%$ were obtained by aqueous-phase TNM nitration of BSA and OVA by Yang et al. (2010).

\subsection{HONO formation}

\subsubsection{HONO formation from nitrated proteins}

To study HONO emission from nitrated proteins, OVA was nitrated with TNM (see Sect. 2.1) in liquid phase. The nitrated OVA $(2 \mathrm{mg} ; \mathrm{ND}=12.5 \%)$ was coated onto the reaction tube and exposed to VIS lights under either pure nitrogen flow or $20 \mathrm{ppb} \mathrm{NO}_{2}$ gas. Strong $\mathrm{HONO}$ emissions were found. A high correlation between $\mathrm{HONO}$ emission and light intensity was observed (50\% RH; Fig. 3). Initially, we did not apply $\mathrm{NO}_{2}$. Thus the observed $\mathrm{HONO}$ formation (up to $950 \mathrm{ppt}$ ) originated from decomposing nitrated proteins rather than from heterogeneous conversion of $\mathrm{NO}_{2}$. However, when exposed to $20 \mathrm{ppb}$ of $\mathrm{NO}_{2}$ in dark conditions, HONO formation increased 4-fold (50-200 ppt) and about 2fold with seven VIS lamps turned on (950-1800 ppt). After $7 \mathrm{~h}$ of flow tube experiments $(4.5 \mathrm{~h}$ irradiation with varying light intensities $(0,1,3,7$ lights $)+2.5 \mathrm{~h}$ irradiation $/ 20 \mathrm{ppb}$ $\mathrm{NO}_{2}$ (7, 3, 0 lights)), no intact protein was found according to the analysis of HPLC-DAD.

As proteins can efficiently be nitrated by $\mathrm{O}_{3}$ and $\mathrm{NO}_{2}$ in polluted air (Franze et al., 2005; Shiraiwa et al., 2012; Reinmuth-Selzle et al., 2014), the emission of HONO from light-induced decomposing nitrated proteins could play an important role in the HONO budget. As proteins are nitrated at their tyrosine residues (at the ortho position to the $\mathrm{OH}$ group on the aromatic ring) the underlying mechanism of this HONO formation should be very similar to the HONO formation by photolysis of ortho-nitrophenols described by Bejan et al. (2006). This starts with a photo-induced hydrogen transfer from the $\mathrm{OH}$ group to the vicinal $\mathrm{NO}_{2}$ group (Fig. 1),

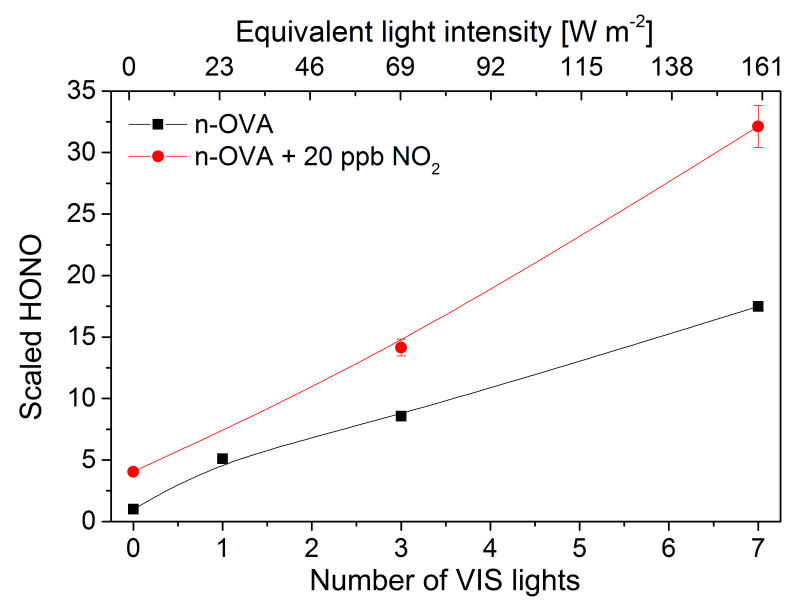

Figure 3. Light-enhanced HONO formation from TNM-nitrated proteins (n-OVA: ND $12.5 \%$, coating $21.5 \mu \mathrm{g} \mathrm{cm}^{-2}$ ). Black squares indicate $\mathrm{HONO}$ formation via decomposition from nitrated proteins (without $\mathrm{NO}_{2}$ ) while red squares indicate additional $\mathrm{HONO}$ formation via heterogeneous $\mathrm{NO}_{2}$ conversion $(20 \mathrm{ppb} \mathrm{NO}$ ) at $50 \%$ $\mathrm{RH}$ (HONO is scaled to the HONO concentration measured without $\mathrm{NO}_{2}$ and no light $\left([\mathrm{HONO}]_{\text {lights; } \mathrm{NO}_{2}} /[\mathrm{HONO}]_{\text {dark; }} \mathrm{NO}_{2}=0\right)$ ).

which leads to an excited intermediate from which HONO is eliminated subsequently.

\subsubsection{Light dependency}

To investigate HONO formation on unmodified BSA coating $\left(31.4 \mu \mathrm{g} \mathrm{cm}^{-2}\right)$ dependent on light conditions, the radiation intensity (number of VIS lamps) was changed under otherwise constant conditions of exposure at $20 \mathrm{ppb} \mathrm{NO}_{2}$ and $50 \%$ RH. Decreasing light intensity revealed a linearly decreasing trend in HONO formation from about 1000 to $140 \mathrm{ppt}$ (red symbols in Fig. 4). After re-illumination to the initial high light intensity the HONO formation was reduced by $32 \%$ (blue symbol in Fig. 4). Stemmler et al. (2006) and Sosedova et al. (2011) also observed a similar saturation of HONO formation on humic, tannic and gentisic acid at higher light intensities. Stemmler et al. (2006) argued that surface sites activated for $\mathrm{NO}_{2}$ heterogeneous conversion by light (Reaction R3) would become de-activated by competition with photo-induced oxidants ( $\mathrm{X}^{*}$, Reactions R7-R8), e.g., primary chromophores or electron donors are oxidized by surface*, which is in line with the observed decomposition of the native protein presented above.

surface $\stackrel{h v}{\longrightarrow}$ surface $^{*} \stackrel{\mathrm{NO}_{2}}{\longrightarrow} \mathrm{HONO}+$ surface $_{\mathrm{ox}}$

$\mathrm{X} \stackrel{h v}{\longrightarrow} \mathrm{X}^{*} \stackrel{\text { surface* }}{\longrightarrow}$ surface- $\mathrm{X}$

In other studies the $\mathrm{NO}_{2}$ uptake coefficient on soot, mineral dust, humic acid and other solid organic compounds similarly increased at increasing light intensities (George et al., 2005; Stemmler et al., 2007; Ndour et al., 2008; Monge 
(a)

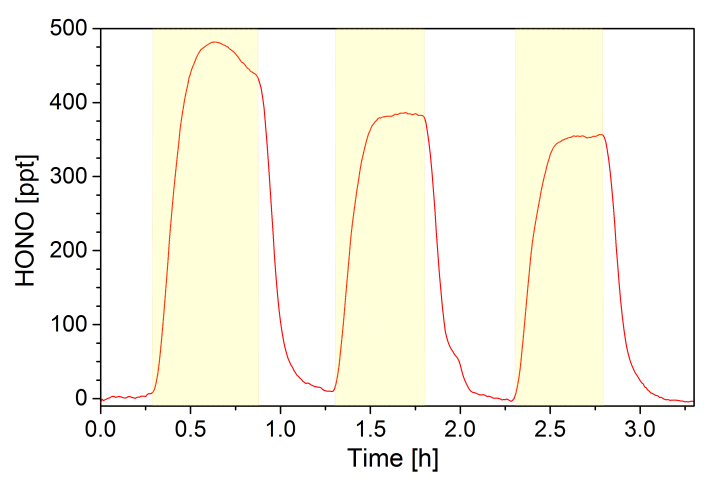

(b)

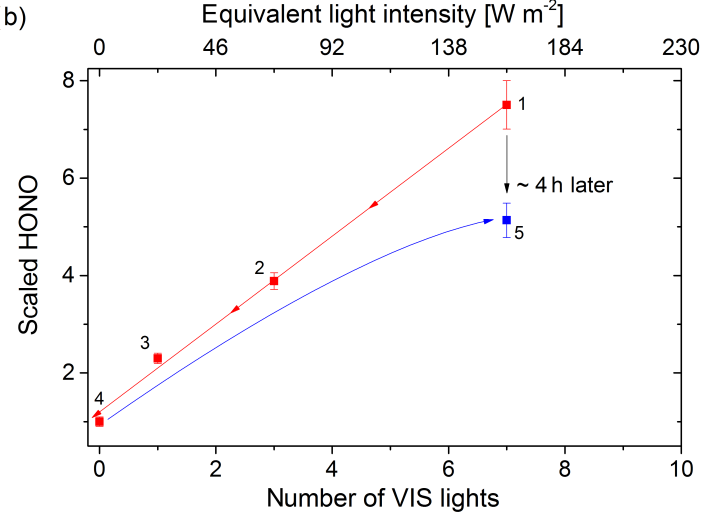

Figure 4. Light-induced HONO formation on BSA. (a) HONO formation under alternating dark and light conditions on BSA surface $\left(22.5 \mu \mathrm{g} \mathrm{cm}^{-2}\right)$; yellow shaded areas indicate periods in which seven VIS lamps were switched on $\left(\mathrm{RH}=50 \%, \mathrm{NO}_{2}=20 \mathrm{ppb}\right)$. (b) Dependency of HONO formation on radiation intensity at $20 \mathrm{ppb} \mathrm{NO}$ and $50 \% \mathrm{RH}\left(\mathrm{BSA}=31.4 \mu \mathrm{g} \mathrm{cm}^{-2}\right)$. The experiment started with seven VIS lights switched on, sequentially decreasing the number of lights (red symbols, nominated 1-4), prior to applying the initial irradiance again (blue symbol, 5). HONO was scaled to the HONO concentration in darkness ([HONO $\left.]_{\text {lights }} /[\mathrm{HONO}]_{\text {dark }}\right)$. Error bars indicate SD of 20-30 min measurements; SD of point 5 covers $2.75 \mathrm{~h}$ measurement.

et al., 2010; Han et al., 2016; Brigante et al., 2008). Note that the $\mathrm{HONO}$ yield (ratio of $\mathrm{HONO}$ formed to $\mathrm{NO}_{2}$ lost) was found to be constant at light intensities in the range of 60 $200 \mathrm{~W} \mathrm{~m}^{-2}$ in the work of Han et al. (2016) but has shown a linear dependence on light for nitrated phenols (Bejan et al., 2006).

\subsection{3 $\quad \mathrm{NO}_{2}$ dependency}

At about $50 \%$ relative humidity and high illumination intensities (seven VIS lamps, $\sim 161 \mathrm{Wm}^{-2}$ ), heterogeneous formation of HONO strongly correlated with the applied $\mathrm{NO}_{2}$ concentration (Fig. 5). On a BSA surface of about $16.1 \mu \mathrm{g} \mathrm{cm}^{-2}$ (Table 1) the produced HONO concentration increased from $56 \mathrm{ppt}$ at $20 \mathrm{ppb} \mathrm{NO}_{2}$ to $160 \mathrm{ppt}$ at $100 \mathrm{ppb}$ $\mathrm{NO}_{2}$. Only at a threshold $\mathrm{NO}_{2}$ level well above those typically observed in natural environments $(\gg 150 \mathrm{ppb})$ did this increasing trend slow down to some extent, indicative of saturation of active surface sites. A similar pattern of $\mathrm{NO}_{2}$ dependence was also observed for light-induced HONO formation from humic acid (Stemmler et al., 2006) and phenolic compounds like gentisic and tannic acid (Sosedova et al., 2011) or polycyclic aromatic hydrocarbons (Brigante et al., 2008) and for heterogeneous $\mathrm{NO}_{2}$ conversion on soot under dark conditions (Stadler and Rossi, 2000; Salgado and Rossi, 2002; Arens et al., 2001).

For better comparison of the different studies the HONO concentration measured at different $\mathrm{NO}_{2}$ concentrations was scaled to the $\mathrm{HONO}$ concentration at $20 \mathrm{ppb} \mathrm{NO}_{2}$ $\left([\mathrm{HONO}]_{\mathrm{NO}_{2}} /[\mathrm{HONO}]_{\mathrm{NO}_{2}}=20 \mathrm{ppb}\right)$ in Fig. 5, as variable absolute amounts of $\mathrm{HONO}$ were found in different studies and matrices. A cease of the $\mathrm{NO}_{2}$ dependency on heterogeneous HONO formation can be assessed for most of the studies at $\mathrm{NO}_{2}$ concentrations $\geq 200 \mathrm{ppb}$. A very similar correlation

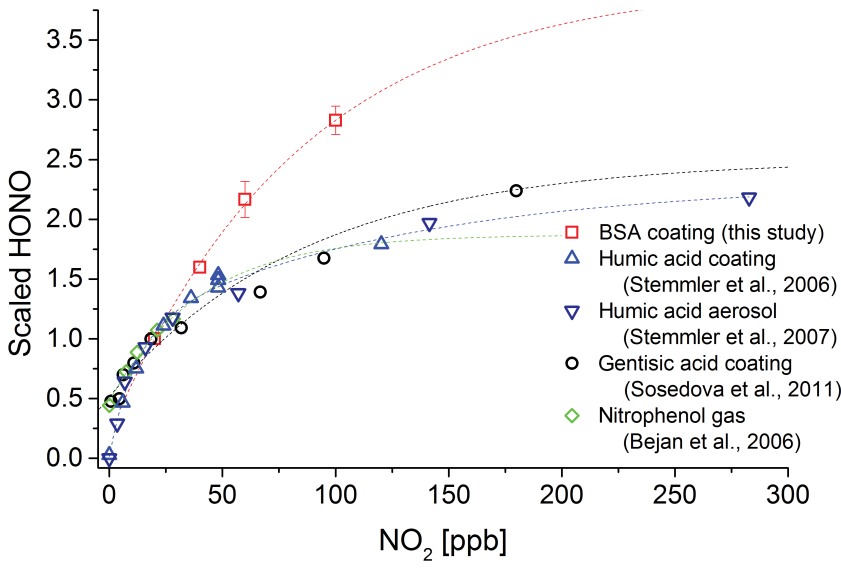

Figure 5. Comparison of HONO formation dependency on $\mathrm{NO}_{2}$ at different organic surfaces. HONO concentrations are scaled to the $\mathrm{HONO}$ concentration at $20 \mathrm{ppb} \mathrm{NO}_{2}$ $\left([\mathrm{HONO}]_{\mathrm{NO}_{2}} /[\mathrm{HONO}]_{\mathrm{NO}_{2}}=20 \mathrm{ppb}\right)$. The red squares indicate BSA coating $\left(16 \mu \mathrm{g} \mathrm{cm}^{-2}\right)$ at $161 \mathrm{Wm}^{-2}$ and $50 \% \mathrm{RH}$ (this study). Blue triangles pointing up are humic acid coating $\left(8 \mu \mathrm{g} \mathrm{cm}^{-2}\right)$ at $162 \mathrm{~W} \mathrm{~m}^{-2}$ and $20 \% \mathrm{RH}$ (Stemmler et al., 2006), while the blue triangles pointing down are the humic acid aerosol with $100 \mathrm{~nm}$ diameter and a surface of $0.151 \mathrm{~m}^{2} \mathrm{~m}^{-3}$ at $26 \% \mathrm{RH}$ and $1 \times 10^{17}$ photons $\mathrm{cm}^{-2} \mathrm{~s}^{-1}$ (Stemmler et al., 2007). The black circles are gentisic acid coating (160-200 $\left.\mu^{g_{\mathrm{cm}}}{ }^{-2}\right)$ at $40-45 \% \mathrm{RH}$ and light intensity similar to that in the humic acid aerosol study (Sosedova et al., 2011). Green diamonds are ortho-nitrophenol in gas phase (ppm level) illuminated with UV/VIS light. Dotted lines are exponential fittings of the measured data points and are meant to guide the eyes.

(up to $40 \mathrm{ppb} \mathrm{NO}_{2}$ ) was observed when $\mathrm{NO}_{2}$ was applied additionally during the gas-phase photolysis of nitrophenols (Fig. 5; Bejan et al., 2006). Even though the matrix (nitro- 
phenols) and conditions (illuminated) of the latter is comparable to the experiment presented here, for BSA no clear indication of saturation was found up to $160 \mathrm{ppb}$ of $\mathrm{NO}_{2}$, pointing to a highly reactive surface of BSA for $\mathrm{NO}_{2}$ under illuminated conditions. As shown with Reactions (R7) and (R8), the concentration dependence depends on the competing channel (Reaction R8); therefore, this is strongly matrix dependent, both in terms of chemical and physical properties.

\subsubsection{Impact of coating thickness}

Strong differences in HONO concentrations were found for experiments with different coating thicknesses applying otherwise similar conditions ( $20 \mathrm{ppb}$ of $\mathrm{NO}_{2}$, seven VIS lamps and $50 \% \mathrm{RH})$. While only $55 \mathrm{ppt}$ of HONO concentration was observed for a shallow homogeneous coating of $16.1 \mu \mathrm{g} \mathrm{cm}^{-2}$ (217.6 nm thickness, see below) applied on the whole length of the tube, up to $2 \mathrm{ppb}$ was found for a thick (more uneven) coating of $31.44 \mu \mathrm{g} \mathrm{cm}^{-2}$ (435.2 nm thickness) covering only $50 \%$ of the tube (Fig. 6). Potential explanations are that thicker coating leads to (1) more bulk reactions producing HONO or (2) different morphologies, e.g., higher effective reaction surfaces. Exposing (20\%) different coated surface areas in the flow tube, potentially introduced bias comparing different data sets. Emitted HONO might be re-adsorbed differently by proteins and glass surface. However, as the protein is slightly acidic, a low uptake efficiency of HONO by BSA can be anticipated, which should not differ too much from the uncovered glass tube surface (Syomin and Finlayson-Pitts, 2003). Accordingly, $\mathrm{NO}_{2}$ uptake on glass is assumed to be significantly lower than on proteins. A strong increase in $\mathrm{NO}_{2}$ uptake coefficients with increasing coating thickness was also observed for humic acid coatings (Han et al., 2016). However, they found an upper threshold value of $2 \mu \mathrm{g} \mathrm{cm}^{-2}$ of cover load ( $20 \mathrm{~nm}$ absolute thickness, assuming a humic acid density of $1 \mathrm{~g} \mathrm{~cm}^{-3}$ ), above which uptake coefficients were found to be constant. The authors also proposed that $\mathrm{NO}_{2}$ can diffuse deeper into the coating and below $2 \mu \mathrm{g} \mathrm{cm}^{-2}$ the full cover depth would react with $\mathrm{NO}_{2}$, respectively.

For proteins the number of molecules per monolayer depends on their orientation and respective layer thickness can vary accordingly. One (dry, crystalline) BSA molecule has a volume of about $154 \mathrm{~nm}^{3}$ (Bujacz, 2012). In a flat orientation $(4.4 \mathrm{~nm}$ layer height and a projecting area of $35 \mathrm{~nm}^{2}$ molecule $\left.{ }^{-1}\right) 3.64 \times 10^{14}$ molecules $(40.5 \mu \mathrm{g}$; $0.32 \mu \mathrm{g} \mathrm{cm}^{-2}$ ) of BSA are needed to form one complete monolayer in the flow tube (i.d. of $0.81,50 \mathrm{~cm}$ length, $100 \%$ surface coating). Hence, the thinnest BSA coating applied in the experiment $\left(16.1 \mu \mathrm{g} \mathrm{cm}^{-2}\right)$ would consist of 50 monolayers, revealing a total coating thickness of $217.6 \mathrm{~nm}$, and the thickest BSA coating $\left(31 \mu \mathrm{g} \mathrm{cm}^{-2}\right)$ would have 99 monolayers and an absolute thickness of $435.1 \mathrm{~nm}$. At the other extreme (non-flat) orientation, more BSA molecules are needed to sustain one monolayer. With $21.7 \mathrm{~nm}^{2}$ of pro-

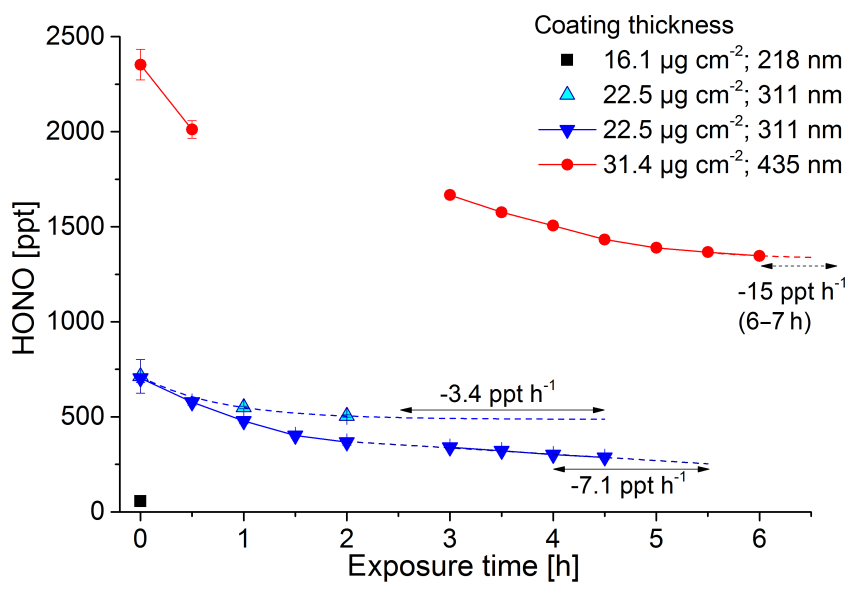

Figure 6. HONO formation on three different BSA coating thicknesses, exposed to $20 \mathrm{ppb}$ of $\mathrm{NO}_{2}$ under illuminated conditions (seven VIS lamps). The HONO concentrations were scaled to reaction tube coverage (black: $100 \%$ of reaction tube was covered with BSA; light blue: $70 \%$ of tube was covered; red: $50 \%$ of tube was covered with BSA). The middle thick coating $\left(22.46 \mu \mathrm{g} \mathrm{cm}^{-2}\right)$ was replicated and studied with different reaction times (cyan and blue triangle). Solid lines (with circles or triangles) present continuous measurements; when those are interrupted, other conditions (e.g., light intensity, $\mathrm{NO}_{2}$ concentration) prevailed. Dotted lines show interpolations and are meant to guide the eyes. Arrows indicate the intervals in which the shown decay rates were determined. Error bars indicates SDs from 10 to 20 measuring points (5-10 min).

jected area of one molecule and $7.1 \mathrm{~nm}$ monolayer height, $5.86 \times 10^{14}$ molecules of BSA are needed to form one complete monolayer in the flow tube. The coatings would consist of between 31 (thinnest) and 61 (thickest) monolayers of BSA. With a flat orientation 1-2\% (number or weight) of BSA molecules would build the uppermost surface monolayer, whereas in an upright molecule orientation 1.6-3.3\% would be in direct contact with surface ambient air.

In the crystalline form several molecules of water stick tightly to BSA. As BSA is highly hygroscopic, more water molecules are adsorbed at higher relative humidity. At $35 \%$ RH BSA is deliquesced (Mikhailov et al., 2004). Therefore the above described number of monolayers and the absolute layer thickness are a lower bound estimate.

In conclusion, the thickness dependence on HONO formation is extremely complex. Activation and photolysis of nitrated Tyr occurs throughout the BSA layer. The heterogeneous reaction of $\mathrm{NO}_{2}$ may or may be not limited to the surface depending on solubility and diffusivity of $\mathrm{NO}_{2}$. Also the release of HONO may be limited by diffusion. The observed dependence on the coating thickness suggests the involvement of the bulk reactions, but the reactions can happen in both surface and bulk phase. 


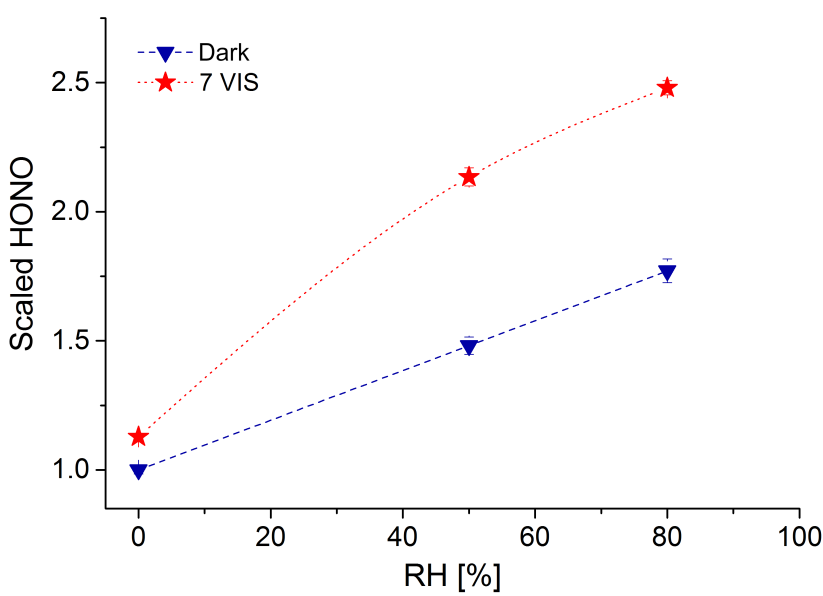

Figure 7. Dependency of relative humidity on HONO formation. $25 \mathrm{ppb} \mathrm{NO}_{2}$ was applied on BSA surface $\left(17.5 \mu \mathrm{g} \mathrm{cm}^{-2}\right)$ either in darkness (blue triangle) or at seven VIS lights (red star). HONO was scaled to HONO concentrations in darkness under dry conditions ([HONO $]_{\text {lights on-off; } \mathrm{RH}} /[\mathrm{HONO}]_{\text {dark; } \mathrm{RH}=0}$ ). Dotted lines are meant to guide the eyes.

\subsubsection{RH dependency}

The dependence of HONO emission on relative humidity is shown in Fig. 7. Here about $25 \mathrm{ppb}$ of $\mathrm{NO}_{2}$ was applied to a (not nitrated) BSA-coated flow tube $\left(17.5 \mu \mathrm{g} \mathrm{cm}^{-2}\right)$ both in dark and illuminated conditions (seven VIS lights). HONO formation scaled with relative humidity. Kleffmann et al. (1999) proposed that higher humidity inhibits the self-reaction of $\mathrm{HONO}\left(2 \mathrm{HONO}_{(\mathrm{s}, \mathrm{g})} \rightarrow \mathrm{NO}_{2}+\mathrm{NO}+\mathrm{H}_{2} \mathrm{O}\right)$, which leads to higher $\mathrm{HONO}$ yield from heterogeneous $\mathrm{NO}_{2}$ conversion.

The RH dependence of HONO formation on proteins is different to other surfaces. For example, no influence of $\mathrm{RH}$ has been observed for dark heterogeneous HONO formation on soot particles sampled on filters (Arens et al., 2001). No impact of humidity on $\mathrm{NO}_{2}$ uptake coefficients on pyrene was detected (Brigante et al., 2008). For HONO formation on tannic acid coatings (both at dark and irradiated conditions) a linear but relatively weak dependence has been reported between 10 and $60 \% \mathrm{RH}$, while below $10 \%$ and above $60 \%$ $\mathrm{RH}$ the correlation between HONO formation and RH was much stronger (Sosedova et al., 2011). Similar results were obtained for anthrarobin coatings by Arens et al. (2002). This type of dependence of HONO formation on phenolic surfaces on RH equals the HONO formation on glass, following the BET water uptake isotherm of water on polar surfaces (Finnlayson-Pitts et al., 2003; Summer et al., 2004). For humic acid surfaces the $\mathrm{NO}_{2}$ uptake coefficients also weakly increased below $20 \% \mathrm{RH}$ and were found to be constant between 20 and $60 \%$ (Stemmler et al., 2007).

While on solid matter chemical reactions are essentially confined to the surface rather than in the bulk, proteins can adopt an amorphous solid or semisolid state, influencing the rate of heterogeneous reactions and multiphase processes. Molecular diffusion in the non-solid phase affects the gas uptake and respective chemical transformation. Shiraiwa et al. (2011) could show that the ozonolysis of amorphous protein is kinetically limited by bulk diffusion. The reactive gas uptake exhibits a pronounced increase with relative humidity, which can be explained by a decrease of viscosity and increase of diffusivity, as the uptake of water transforms the amorphous organic matrix from a glassy to a semisolid state (moisture-induced phase transition). The viscosity and diffusivity of proteins depend strongly on the ambient relative humidity because water can act as a plasticizer and increase the mobility of the protein matrix (for details see Shiraiwa et al., 2011, and references therein). Shiraiwa et al. (2011) further showed that the BSA phase changes from solid through semisolid to viscous liquid as RH increases, while trace gas diffusion coefficients increased about 10 orders of magnitude. This way, characteristic times for heterogeneous reaction rates can decrease from seconds to days as the rate of diffusion in semisolid phases can decrease by multiple orders of magnitude in response to both low temperature (not investigated in here) and/or low relative humidity. Accordingly, we propose that HONO formation rate depends on the condensed-phase diffusion coefficients of $\mathrm{NO}_{2}$ diffusing into the protein bulk, $\mathrm{HONO}$ released from the bulk and mobility of excited intermediates.

\subsubsection{Long-term exposure with $\mathrm{NO}_{2}$ under irradiated conditions}

To study long-term effects of irradiation on HONO formation from proteins, flow tubes were coated with $2 \mathrm{mg}$ BSA $\left(17.5 \pm 0.4 \mu \mathrm{g} \mathrm{cm}^{-2} ; 90 \%\right.$ of total length) and exposed to $100 \mathrm{ppb} \mathrm{NO}_{2}$, at $80 \% \mathrm{RH}$ at illuminated conditions for a time period of up to $20 \mathrm{~h}$ (Fig. 8). Samples illuminated with VIS light only (red and orange colored lines in Fig. 8) showed persistent $\mathrm{HONO}$ emissions over the whole measurement period. For unknown reasons, and even though the observed HONO concentrations were within the expected range with regard to the applied $\mathrm{NO}_{2}$ concentrations, $\mathrm{RH}$ and cover characteristics, one sample (orange in Fig. 8) showed a sharp short-term increase in the initial phase followed by respective decrease, not in line with all other samples (compare Fig. 6). However, after $4 \mathrm{~h}$ both VIS irradiated samples showed virtually constant HONO emissions $\left(-3.8\right.$ and $+1.6 \mathrm{ppth}^{-1}$, respectively). The sample illuminated with UV and VIS light (three UV and four VIS lamps) showed a sustained sharp increase in the first $4 \mathrm{~h}$, followed by persistent and very stable (decay rate as low as $-0.5 \mathrm{ppth}^{-1}$ ) HONO emissions at an about 3-fold higher level compared to samples irradiated with VIS only. HONO formation by photolysis of (adsorbed) $\mathrm{HNO}_{3}$ is assumed to be insignificant in this study. With $\mathrm{N}_{2}$ as carrier gas, gas-phase reactions of $\mathrm{NO}_{2}$ do not produce $\mathrm{HNO}_{3}$. Even when small amounts of $\mathrm{HNO}_{3}$ would 

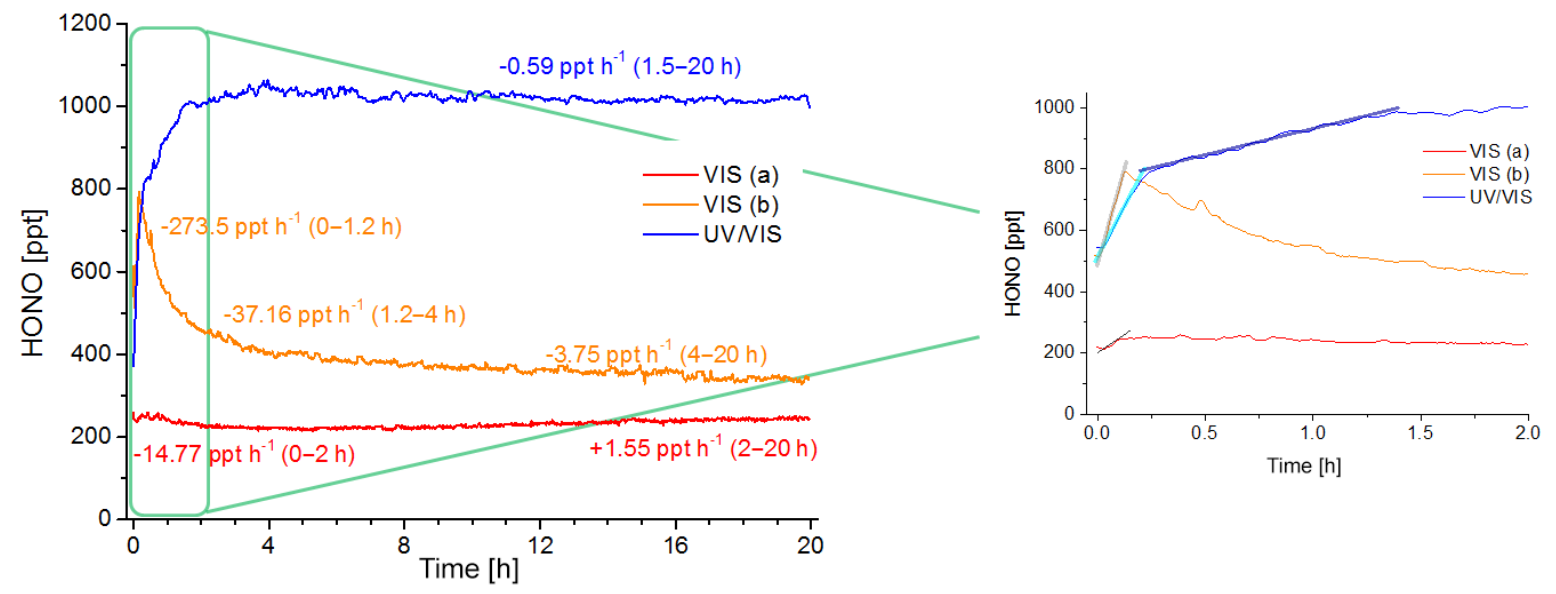

Figure 8. Extended measurements $\left(20 \mathrm{~h}\right.$ ) of light-enhanced HONO formation on BSA (three coatings of $17.5 \mu \mathrm{g} \mathrm{cm}{ }^{-2}$ ) at $80 \% \mathrm{RH}, 100 \mathrm{ppb}$ $\mathrm{NO}_{2}$. HONO formation under VIS light is shown in red and orange, under UV/VIS light in blue. HONO decay rates (ppth ${ }^{-1}$ ) are shown with time periods (in brackets) in which they were calculated, suggesting a stable HONO formation after $4 \mathrm{~h}$. Right: magnification of the first $2 \mathrm{~h}$. Straight lines (black, grey, light and dark blue) show the slopes of which $\mathrm{d}[\mathrm{HONO}] / \mathrm{d} t$ were used in the kinetic studies.

be formed by unknown heterogeneous reactions, photolysis of $\mathrm{HNO}_{3}$ is only significant at wavelengths $<350 \mathrm{~nm}$, which is close to the lowest limit of the UV wavelength applied in this study. Likewise, the respective photolysis frequency recently proposed by Laufs and Kleffmann (2016) of about $2.4 \times 10^{-7} \mathrm{~s}^{-1}$ is very low.

Integrating the $20 \mathrm{~h}$ experiments, $9.23 \times 10^{15}(4.6 \mathrm{ppbh}$, VISa), $1.53 \times 10^{16}(7.7 \mathrm{ppbh}, \quad \mathrm{VISb})$ and $4.01 \times 10^{16}$ (20 ppbh, UV/VIS) molecules of HONO were produced. This means between $7.7 \times 10^{13}$ and $3.3 \times 10^{14}$ molecules of HONO per $\mathrm{cm}^{2}$ of BSA geometric surface were formed. With respect to the different experimental conditions concerning cover thickness, $\mathrm{RH}$, and $\mathrm{NO}_{2}$ concentrations, this is in a similar order of magnitude as found for humic acid $\left(2 \times 10^{15}\right.$ molecules $\mathrm{cm}^{-2}$ in $\left.13 \mathrm{~h}\right)$ by Stemmler et al. (2006).

If BSA acts like a catalytic surface as in a LangmuirHinshelwood reaction each BSA molecule can react several times with $\mathrm{NO}_{2}$ to heterogeneously form HONO. As described in 3.1, BSA nitration is in competition with $\mathrm{NO}_{2}$ surface reactions and only a limited number of $\mathrm{NO}_{2}$ molecules could react with BSA forming HONO via nitration of proteins and subsequent decomposition of nitrated proteins. A BSA molecule contains 21 tyrosine residues, which could react with $\mathrm{NO}_{2}$. However, even a strong nitration agent such as TNM is not capable of nitrating all tyrosine residues and a mean ND of $19 \%$ was found (Peterson et al., 2001; Yang et al., 2010); i.e., four tyrosine residues of one BSA molecule can be nitrated to form HONO. As 2 mg of BSA was applied for each flow tube coating, a total of $1.8 \times 10^{16}$ protein molecules can be inferred. In $20 \mathrm{~h}$ of irradiating with VIS light $13-22 \%$ of the accessible Tyr residues (four Tyr per BSA molecule) would have been reacted. Irradiating with additional UV lights at least $56 \%$ of the tyrosine residues would have been nitrated and decomposed. However, as $\mathrm{NO}_{2}$ is a much weaker nitrating agent and nitration of only one tyrosine residue is probable (ND of BSA with $\mathrm{O}_{3} / \mathrm{NO}_{2} 6 \%$; Yang et al., 2010) up to $85 \%$ BSA molecules would have been reacted when irradiated with VIS lights and even more HONO molecules as coated BSA molecules would have been generated under UV/VIS light conditions. Other amino acids of the protein like tryptophan or phenylalanine might also be nitrated but without formation of HONO (Goeschen et al., 2011). Hence, a contribution of heterogeneous conversion of $\mathrm{NO}_{2}$ can be anticipated.

\subsection{Kinetic studies}

The experimental results (especially the stability over a long time) indicate that the formation of $\mathrm{HONO}$ from $\mathrm{NO}_{2}$ on protein surfaces likely underlies the Langmuir-Hinshelwood mechanism in which the protein would act as a catalytic surface (Fig. 9). The first step is the fast, reversible physical adsorption of $\mathrm{NO}_{2}\left(k_{1}\right)$ and water followed by the slow conversion into HONO.

There are two possible processes for the HONO formation. $\mathrm{HONO}$ is formed by heterogeneous $\mathrm{NO}_{2}$ conversion $\left(k_{2}\right)$ but also via nitration and decomposition of nitrated proteins $\left(k_{4}\right.$, $k_{5}$ ). The final step of the mechanism is the release of the generated HONO into the air. Since proteins are in general slightly acidic, the desorption of $\mathrm{HONO}\left(k_{3}\right)$ should be fairly fast. Pseudo-first-order kinetics are assumed for the reaction of $\mathrm{NO}_{2}$ to $\mathrm{HONO}$ (Stemmler et al., 2007) and the reaction can be described as follows (Eq. 1).

$$
\frac{\mathrm{d}[\mathrm{HONO}]_{\mathrm{g}}}{\mathrm{d} t}=k_{\mathrm{eff}} \cdot\left[\mathrm{NO}_{2}\right]_{\mathrm{g}},
$$

with $k_{\text {eff }}$ the effective pseudo-first-order rate constant (for more detailed information check the Supplement). 


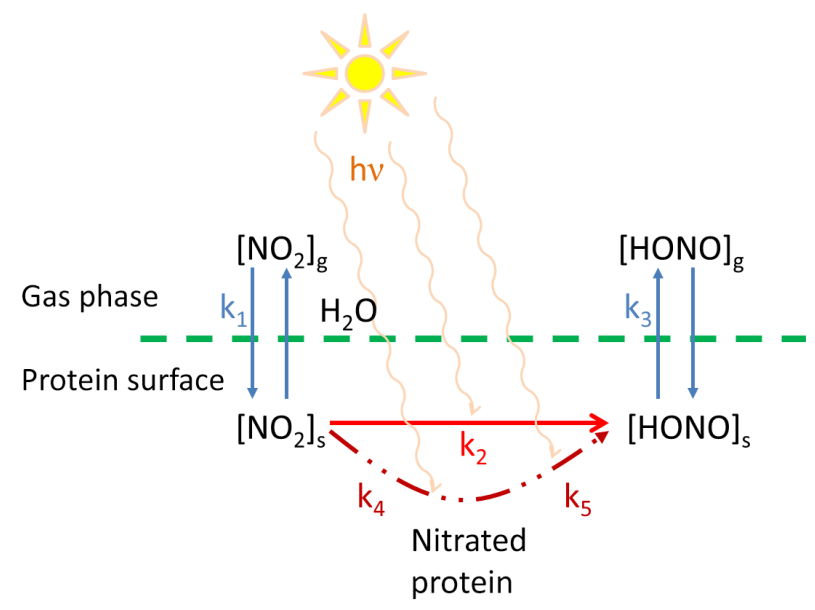

Figure 9. Schematic illustration of the underlying LangmuirHinshelwood mechanism of light-induced HONO formation on protein surface. Reaction constants for $\mathrm{NO}_{2}$ uptake, direct $\mathrm{NO}_{2}$ conversion, protein nitration, HONO formation from decomposing nitrated proteins and HONO release are indicated by $k_{1}, k_{2}, k_{4}, k_{5}$, and $k_{3}$.

In this study, neither $\mathrm{HONO}$ nor $\mathrm{NO}_{2}$ photolysis is considered, as the overlap of the applied UV/VIS or VIS range (340-700 or $400-700 \mathrm{~nm}$ ) and the $\mathrm{HONO}$ and $\mathrm{NO}_{2}$ photolysis spectrum $(<400 \mathrm{~nm})$ is low. Furthermore, the applied light intensity is lower compared to clear-sky irradiance and the respective UV light is partly absorbed by the reaction tube although quartz glass was used (transmission $\sim 90 \%$ ) and the photolysis frequency would decrease down to $10^{-4} \mathrm{~s}^{-1}$. Hence, the photolysis is assumed to be not significant.

In the first 5-10 min of the long-term experiments, HONO increased (Fig. 8 - zoomed in range). This slope was taken as $\mathrm{d}[\mathrm{HONO}]_{\mathrm{g}} / \mathrm{d} t$ in Eq. (6). Effective rate constants between $1.48 \times 10^{-6} \mathrm{~s}^{-1}$ (VISa) and $7.40 \times 10^{-6} \mathrm{~s}^{-1}$ (VISb) were calculated. When irradiating with VIS light only, the concentration of HONO was either constant or decreased for $2 \mathrm{~h}$ after this first $10 \mathrm{~min}$. When irradiating with additional UV light, the HONO signal showed an enhancement in two steps. In the first $10 \mathrm{~min}$ it was strongly increasing $\left(1327 \mathrm{ppth}^{-1}\right)$ and then in the next hour it increased less with $170 \mathrm{ppth}^{-1}$ prior to stabilization. Therefore two rate constants of $4.10 \times 10^{-6}$ and $5.2 \times 10^{-7} \mathrm{~s}^{-1}$ were obtained, respectively.

Reactive uptake coefficients for $\mathrm{NO}_{2}$ were calculated according to Li et al. (2016). For both irradiation types the uptake coefficient $\gamma$ was in the range of $7 \times 10^{-6}$ at the very beginning of each experiment. After a few minutes they decreased to a mean of $1 \times 10^{-7}$. The calculated $k_{\text {eff }}$ values and uptake coefficient are in the same range and match the $\mathrm{NO}_{2}$ uptake coefficients on irradiated humic acid surfaces (coatings) and aerosols obtained by Stemmler et al. (2006/07) which were in between $2 \times 10^{-6}$ and $2 \times 10^{-5}$ (coatings) and $1 \times 10^{-6}$ and $6 \times 10^{-6}$ (aerosols), depending on $\mathrm{NO}_{2}$ concen- trations and light intensities. Similar $\mathrm{NO}_{2}$ uptake coefficients on humic acid were observed by Han et al. (2016). George et al. (2005) reported about a 2 -fold increased $\mathrm{NO}_{2}$ uptake coefficients for irradiated organic substrates (benzophenone, catechol, anthracene) compared to dark conditions, in the order of $(0.6-5) \times 10^{-6} . \mathrm{NO}_{2}$ uptake coefficients on gentisic acid and tannic acid were in between (3.3-4.8) $\times 10^{-7}$ (Sosedova et al., 2011), still higher than on fresh soot or dust (about $1 \times 10^{-7}$; Monge et al., 2010; Ndour et al., 2008). The $\mathrm{NO}_{2}$ uptake coefficients on BSA in the presence of $\mathrm{O}_{3}$ $\left(1 \times 10^{-5}\right.$, for $26 \mathrm{ppb} \mathrm{NO}_{2}$ and $\left.20 \mathrm{ppb} \mathrm{O}_{3}\right)$ published by Shiraiwa et al. (2012) were somewhat higher than the values calculated here without $\mathrm{O}_{3}$ but with light.

It was not possible to extract a set of parameters for a Langmuir-Hinshelwood mechanism (like Langmuir equilibrium constant, surface accommodation coefficient or second-order rate constant) from the presented data. The saturating behavior of photochemical HONO production may be due to either the adsorbed precursor on the surface or due to a photochemical competition process, which also leads to a Lindemann-Hinshelwood type kinetic expression (Minero, 1999).

\section{Summary and conclusion}

Photochemical nitration of proteins accompanied by formation of HONO by (i) heterogeneous conversion of $\mathrm{NO}_{2}$ and (ii) decomposition of nitrated proteins was studied under relevant atmospheric conditions. $\mathrm{NO}_{2}$ concentrations ranged from $20 \mathrm{ppb}$ (typical for urban regions in Europe and USA) up to $100 \mathrm{ppb}$ (representative for highly polluted industrial regions). The applied relative humidity of up to $80 \%$ and light intensities of up to $161 \mathrm{~W} \mathrm{~m}^{-2}$ are common on cloudy days. Under illuminated conditions very low nitration of proteins or even no native protein was observed, indicating a light-induced decomposition of nitrated proteins to shorter peptides. These might still include nitrated residues of which potential health effects are not yet known. An average effective rate constant of the total $\mathrm{NO}_{2}$ HONO conversion of $3.3 \times 10^{-6} \mathrm{~s}^{-1}$ (for about $120 \mathrm{~cm}^{2}$ of protein surface, layer thickness $240 \mathrm{~nm}$ and a layer volume of $0.003 \mathrm{~cm}^{3}$; surface/volume ratio $\sim 40000 \mathrm{~cm}^{-1}$ ) or $8.25 \times 10^{-8} \mathrm{~s}^{-1} \mathrm{~cm}^{-2}$ BSA layer was obtained. At $20 \mathrm{ppb}$ $\mathrm{NO}_{2}$ HONO formation of $19.8 \mathrm{ppbh}^{-1} \mathrm{~m}^{-2}$ on a pure BSA surface could be estimated. While heterogeneous $\mathrm{HONO}$ formation of BSA exposed to $\mathrm{NO}_{2}$ revealed light saturation at intensities higher than $161 \mathrm{~W} \mathrm{~m}^{-2}$, the HONO formation from previously nitrated OVA was linearly increasing over the whole light intensity range investigated. The latter let assume even higher HONO formation under sunny (clear-sky) ambient atmospheric conditions. No data about representative protein surface areas on atmospheric aerosol particles are available. However, the number and mass concentration of primary biological aerosol particles such as pollen, fungal 
spores and bacteria, containing proteins, are in the range of $10-10^{4} \mathrm{~m}^{-3}$ and $10^{-3}-1 \mu \mathrm{g} \mathrm{m}^{-3}$, respectively (Despres et al., 2012; Shiraiwa et al., 2012). Typical aerosol surface concentrations in rural regions are about $100 \mu \mathrm{m}^{2} \mathrm{~cm}^{-3}$. Stemmler et al. (2007) estimated a HONO formation of $1.2 \mathrm{ppth}^{-1}$ on pure humic acid aerosols in environmental conditions. As $\mathrm{NO}_{2}$ uptake coefficients and $\mathrm{HONO}$ formation rates on proteins are similar to humic acid, but only about $5 \%$ of the aerosol mass can be assumed to consist of proteins, it can be anticipated that HONO formation on aerosol is not a significant HONO source in ambient environmental settings. However, proteins on ground surfaces (soil, plants, etc.) might play a more important role. Accordingly, Stemmler et al. (2006 and 2007) suggested that $\mathrm{NO}_{2}$ conversion on soil covered with humic acid would be sufficient to explain missing HONO sources up to $700 \mathrm{ppth}^{-1}$. Therefore it is difficult to estimate the importance of HONO formation on protein surface and its contribution to the HONO budget. In many studies the calculated unknown source strength of daytime HONO formation is within a range of about 200$800 \mathrm{ppth}^{-1}$ (Kleffmann et al., 2005; Acker et al., 2006; Li et al., 2012).

Data availability. Please contact the corresponding authors Hang Su (h.su@mpic.de) or Yafang Cheng (yafang.cheng@mpic.de) for more information on data.

\section{The Supplement related to this article is available online at https://doi.org/10.5194/acp-17-11819-2017- supplement.}

Competing interests. The authors declare that they have no conflict of interest.

The article processing charges for this open-access publication were covered by the Max Planck Society.

Edited by: Alexander Laskin

Reviewed by: three anonymous referees

\section{References}

Acker, K., Moller, D., Wieprecht, W., Meixner, F. X., Bohn, B., Gilge, S., Plass-Dulmer, C., and Berresheim, H.: Strong daytime production of $\mathrm{OH}$ from $\mathrm{HNO}_{2}$ at a rural mountain site, Geophys. Res. Lett., 33, L02809, https://doi.org/10.1029/2005GL024643, 2006.

Alfassi, Z. B.: Selective oxidation of tyrosine oxidation by $\mathrm{NO}_{2}$ and $\mathrm{ClO}_{2}$ at basic pH, Radiat. Phys. Chem., 29, 405-406, 1987.
Alicke, B., Platt, U., and Stutz, J.: Impact of nitrous acid photolysis on the total hydroxyl radical budget during the Limitation of Oxidant Production/Pianura Padana Produzione di Ozono study in Milan, J. Geophys. Res., 107, 8196, https://doi.org/10.1029/2000JD000075, 2002.

Ammann, M., Kalberer, M., Jost, D. T., Tobler, L., Rossler, E., Piguet, D., Gaggeler, H. W., and Baltensperger, U.: Heterogeneous production of nitrous acid on soot in polluted air masses, Nature, 395, 157-160, 1998.

Ammann, M., Rossler, E., Strekowski, R., and George, C.: Nitrogen dioxide multiphase chemistry: uptake kinetics on aqueous solutions containing phenolic compounds, Phys. Chem. Chem. Phys., 7, 2513-2518, https://doi.org/10.1039/B501808K, 2005.

Arens, F., Gutzwiller, L., Baltensperger, U., Gaggeler, H. W., and Ammann, M.: Heterogeneous reaction of $\mathrm{NO}_{2}$ on diesel soot particles, Environ. Sci. Technol., 35, 2191-2199, https://doi.org/10.1021/es000207s, 2001.

Arens, F., Gutzwiller, L., Gaggeler, H. W., and Ammann, M.: The reaction of $\mathrm{NO}_{2}$ with solid anthrarobin (1,2,10-trihydroxyanthracene), Phys. Chem. Chem. Phys., 4, 3684-3690, https://doi.org/10.1039/B201713J, 2002.

Aubin, D. G. and Abbatt, J. P. D.: Interaction of $\mathrm{NO}_{2}$ with hydrocarbon soot: focus on HONO yield, surface modification, and mechanism, J. Phys. Chem.-US, 111, 6263-6273, 2007.

Bensasson, R. V., Land, E. J., and Truscott, T. G.: Excited States and Free Radicals in Biology and Medicine, Oxford University Press, Oxford, 1993.

Bejan, I., Abd El Aal, Y., Barnes, I., Benter, T., Bohn, B., Wiesen, P., and Kleffmann, J.: The photolysis of ortho-nitrophenols: a new gas phase source of HONO, Phys. Chem. Chem. Phys., 8, 20282035, 2006.

Berto, S., De Laurentiis, E., Tota, T., Chiavazza, E., Daniele, P. G., Minella, M., Isaia, M., Brigante, M., and Vione, D.: Properties of the humic-like material arising from the phototransformation of 1-tyrosine, Sci. Total Environ., 545, 434-444, https://doi.org/10.1016/j.scitotenv.2015.12.047, 2016.

Boreen, A. L., Edhlund, B. L., Cotner, J. B., and McNeill, K.: Indirect Photodegradation of Dissolved Free Amino Acids: The Contribution of Singlet Oxygen and the Differential Reactivity of DOM from Various Sources, Environ. Sci. Technol., 42, 54925498, https://doi.org/10.1021/es800185d, 2008.

Brigante, M., Cazoir, D., D’Anna, B., George, C., and Donaldson, D. J.: Photoenhanced uptake of $\mathrm{NO}_{2}$ by pyrene solid films, J. Phys. Chem.-US, 112, 9503-9508, https://doi.org/10.1021/jp802324g, 2008.

Bujacz, A.: Structures of bovine, equine and leporine serum albumin, Acta Crystallogr. D, 68, 1278-1289, https://doi.org/10.1107/S0907444912027047, 2012.

Costabile, F., Amoroso, A., and Wang, F.: Sub- $\mu$ m particle size distributions in a suburban Mediterranean area. Aerosol populations and their possible relationship with HONO mixing ratios, Atmos. Environ., 44, 5258-5268, 2010.

D’Amato, G., Cecchi, L., Bonini, S., Nunes, C., AnnesiMaesano, I., Behrendt, H., Liccardi, G., Popov, T., and Van Cauwenberge, P.: Allergenic pollen and pollen allergy in Europe, Allergy, 62, 976-990, https://doi.org/10.1111/j.13989995.2007.01393.x, 2007. 
Davies, M. J.: Identification of a globin free radical in equine myoglobin treated with peroxides, Biochim. Biophys. Acta, 1077, 8690, https://doi.org/10.1016/0167-4838(91)90529-9, 1991.

Després, V., Huffman, J. A., Burrows, S. M., Hoose, C., Safatov, A., Buryak, G., Fröhlich-Nowoisky, J., Elbert, W., Andreae, M., Pöschl, U., and Jaenicke, R.: Primary biological aerosol particles in the atmosphere: a review, Tellus B, 64, 15598, https://doi.org/10.3402/tellusb.v64i0.15598, 2012.

Elshorbany, Y. F., Steil, B., Brühl, C., and Lelieveld, J.: Impact of HONO on global atmospheric chemistry calculated with an empirical parameterization in the EMAC model, Atmos. Chem. Phys., 12, 9977-10000, https://doi.org/10.5194/acp-129977-2012, 2012.

Elshorbany, Y. F., Crutzen, P. J., Steil, B., Pozzer, A., Tost, H., and Lelieveld, J.: Global and regional impacts of HONO on the chemical composition of clouds and aerosols, Atmos. Chem. Phys., 14, 1167-1184, https://doi.org/10.5194/acp-141167-2014, 2014.

Finlayson-Pitts, B. J., Wingen, L. M., Sumner, A. L., Syomin, D., and Ramazan, K. A.: The heterogeneous hydrolysis of $\mathrm{NO}_{2}$ in laboratory systems and in outdoor and indoor atmospheres: an integrated mechanism, Phys. Chem. Chem. Phys., 5, 223-242, https://doi.org/10.1039/b208564j, 2003.

Franze, T., Krause, K., Niessner, R., and Pöeschl, U.: Proteins and amino acids in air particulate matter, J. Aerosol Sci., 34, S777S778, 2003.

Franze, T., Weller, M. G., Niessner, R., and Pöschl, U.: Protein nitration by polluted air, Environ. Sci. Technol., 39, 1673-1678, https://doi.org/10.1021/es0488737, 2005.

Gardner, E. P., Sperry, P. D., and Calvert, J. G.: Primary quantum yields of $\mathrm{NO}_{2}$ photodissociation, J. Geophys. Res., 92, 66426652, https://doi.org/10.1029/JD092iD06p06642, 1987.

George, C., Strekowski, R. S., Kleffmann, J., Stemmler, K., and Ammann, M.: Photoenhanced uptake of gaseous $\mathrm{NO}_{2}$ on solidorganic compounds: a photochemical source of HONO?, Faraday Discuss., 130, 195-210, 2005.

Goeschen, C., Wibowo, N., White, J. M., and Wille, U.: Damage of aromatic amino acids by the atmospheric

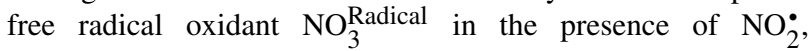
$\mathrm{N}_{2} \mathrm{O}_{4}, \mathrm{O}_{3}$ and $\mathrm{O}_{2}$, Org. Biomol. Chem., 9, 3380-3385, https://doi.org/10.1039/C0OB01186J, 2011.

Gruijthuijsen, Y. K., Grieshuber, I., Stoecklinger, A., Tischler, U., Fehrenbach, T., Weller, M. G., Vogel, L., Vieths, S., Poeschl, U., and Duschl, A.: Nitration enhances the allergenic potential of proteins, Int. Arch. Allergy Imm., 141, 265-275, 2006.

Gutzwiller, L., Arens, F., Baltensperger, U., Gäggeler, H. W., and Ammann, M.: Significance of Semivolatile Diesel Exhaust Organics for Secondary HONO Formation, Environ. Sci. Technol., 36, 677-682, https://doi.org/10.1021/es015673b, 2002.

Han, C., Liu, Y., and He, H.: Role of Organic Carbon in Heterogeneous Reaction of NO2 with Soot, Environ. Sci. Technol., 47, 3174-3181, https://doi.org/10.1021/es304468n, 2013.

Han, C., Yang, W. J., Wu, Q. Q., Yang, H., and Xue, X. X.: Heterogeneous photochemical conversion of $\mathrm{NO}_{2}$ to $\mathrm{HONO}$ on the humic acid surface under simulated sunlight, Environ. Sci. Technol., 50, 5017-5023, 2016.

Heland, J., Kleffmann, J., Kurtenbach, R., and Wiesen, P.: A new instrument to measure gaseous nitrous acid (HONO) in the atmosphere, Environ. Sci. Technol., 35, 3207-3212, 2001.
Houee-Levin, C., Bobrowski, K., Horakova, L., Karademir, B., Schoneich, C., Davies, M. J., and Spickett, C. M.: Exploring oxidative modifications of tyrosine: an update on mechanisms of formation, advances in analysis and biological consequences, Free Radical Res., 49, 347-373, https://doi.org/10.3109/10715762.2015.1007968, 2015.

Johnston, H. S., Davis, H. F., and Lee, Y. T.: $\mathrm{NO}_{3}$ photolysis product channels: quantum yields from observed energy thresholds, J. Phys. Chem.-US, 100, 4713-4723, https://doi.org/10.1021/jp952692x, 1996.

Kalberer, M., Ammann, M., Arens, F., Gaggeler, H. W., and Baltensperger, U.: Heterogeneous formation of nitrous acid (HONO) on soot aerosol particles, J. Geophys. Res., 104, 13825-13832, 1999.

Kampf, C. J., Liu, F., Reinmuth-Selzle, K., Berkemeier, T., Meusel, H., Shiraiwa, M., and Pöschl, U.: Protein cross-linking and oligomerization through dityrosine formation upon exposure to ozone, Environ. Sci. Technol., 49, 10859-10866, https://doi.org/10.1021/acs.est.5b02902, 2015.

Kleffmann, J., H. Becker, K., Lackhoff, M., and Wiesen, P.: Heterogeneous conversion of $\mathrm{NO}_{2}$ on carbonaceous surfaces, Phys. Chem. Chem. Phys., 1, 5443-5450, 1999.

Kleffmann, J., Gavriloaiei, T., Hofzumahaus, A., Holland, F., Koppmann, R., Rupp, L., Schlosser, E., Siese, M., and Wahner, A.: Daytime formation of nitrous acid: a major source of $\mathrm{OH}$ radicals in a forest, Geophys. Res. Lett., 32, L05818, https://doi.org/10.1029/2005GL022524, 2005.

Kurtenbach, R., Becker, K. H., Gomes, J. A. G., Kleffmann, J., Lorzer, J. C., Spittler, M., Wiesen, P., Ackermann, R., Geyer, A., and Platt, U.: Investigations of emissions and heterogeneous formation of HONO in a road traffic tunnel, Atmos. Environ., 35, 3385-3394, 2001.

Lang-Yona, N., Shuster-Meiseles, T., Mazar, Y., Yarden, O., and Rudich, Y.: Impact of urban air pollution on the allergenicity of Aspergillus fumigatus conidia: Outdoor exposure study supported by laboratory experiments, Sci. Total Environ., 541, 365371, https://doi.org/10.1016/j.scitotenv.2015.09.058, 2016.

Laufs, S. and J. Kleffmann: Investigations on HONO formation from photolysis of adsorbed $\mathrm{HNO} 3$ on quartz glass surfaces, Phys. Chem. Chem. Phys., 18, 9616-9625, 2016.

Levy, H.: Normal atmosphere: large radical and formaldehyde concentrations predicted, Science, 173, 141-143, 1971.

Li, X., Brauers, T., Häseler, R., Bohn, B., Fuchs, H., Hofzumahaus, A., Holland, F., Lou, S., Lu, K. D., Rohrer, F., Hu, M., Zeng, L. M., Zhang, Y. H., Garland, R. M., Su, H., Nowak, A., Wiedensohler, A., Takegawa, N., Shao, M., and Wahner, A.: Exploring the atmospheric chemistry of nitrous acid (HONO) at a rural site in Southern China, Atmos. Chem. Phys., 12, 1497-1513, https://doi.org/10.5194/acp-12-1497-2012, 2012.

Li, G., Su, H., Li, X., Kuhn, U., Meusel, H., Hoffmann, T., Ammann, M., Pöschl, U., Shao, M., and Cheng, Y.: Uptake of gaseous formaldehyde by soil surfaces: a combination of adsorption/desorption equilibrium and chemical reactions, Atmos. Chem. Phys., 16, 10299-10311, https://doi.org/10.5194/acp-1610299-2016, 2016.

Menetrez, M. Y., Foarde, K. K., Dean, T. R., Betancourt, D. A., and Moore, S. A.: An evaluation of the protein mass of particulate matter, Atmos. Environ., 41, 8264-8274, https://doi.org/10.1016/j.atmosenv.2007.06.021, 2007. 
Meusel, H., Kuhn, U., Reiffs, A., Mallik, C., Harder, H., Martinez, M., Schuladen, J., Bohn, B., Parchatka, U., Crowley, J. N., Fischer, H., Tomsche, L., Novelli, A., Hoffmann, T., Janssen, R. H. H., Hartogensis, O., Pikridas, M., Vrekoussis, M., Bourtsoukidis, E., Weber, B., Lelieveld, J., Williams, J., Pöschl, U., Cheng, Y., and $\mathrm{Su}, \mathrm{H}$.: Daytime formation of nitrous acid at a coastal remote site in Cyprus indicating a common ground source of atmospheric HONO and NO, Atmos. Chem. Phys., 16, 14475-14493, https://doi.org/10.5194/acp-16-14475-2016, 2016.

Miguel, A. G., Cass, G. R., Glovsky, M. M., and Weiss, J.: Allergens in paved road dust and airborne particles, Environ. Sci. Technol., 33, 4159-4168, 1999.

Mikhailov, E., Vlasenko, S., Niessner, R., and Pöschl, U.: Interaction of aerosol particles composed of protein and saltswith water vapor: hygroscopic growth and microstructural rearrangement, Atmos. Chem. Phys., 4, 323-350, https://doi.org/10.5194/acp-4323-2004, 2004.

Minero, C.: Kinetic analysis of photoinduced reactions at the water semiconductor interface, Catal. Today, 54, 205-216, 1999.

Monge, M. E., D’Anna, B., Mazri, L., Giroir-Fendler, A., Ammann, M., Donaldson, D. J., and George, C.: Light changes the atmospheric reactivity of soot, P. Natl. Acad. Sci. USA, 107, 6605-6609, https://doi.org/10.1073/pnas.0908341107, 2010.

Ndour, M., D’Anna, B., George, C., Ka, O., Balkanski, Y., Kleffmann, J., Stemmler, K., and Ammann, M.: Photoenhanced uptake of $\mathrm{NO}_{2}$ on mineral dust: laboratory experiments and model simulations, Geophys. Res. Lett., 35, L05812, https://doi.org/10.1029/2007g1032006, 2008.

Neves-Petersen, M. T., Petersen, S., and Gajula, G. P.: UV Light Effects on Proteins: From Photochemistry to Nanomedicine, in: Molecular Photochemistry - Various Aspects, edited by: Saha, S., InTech, Chapter 7, 125-158, https://doi.org/10.5772/37947, 2012.

Nikogosyan, D. N. and Gorner, H.: Laser-induced photodecomposition of amino acids and peptides: extrapolation to corneal collagen, IEEE J. Sel. Top. Quant., 5, 1107-1115, https://doi.org/10.1109/2944.796337, 1999.

Notholt, J., Hjorth, J., and Raes, F.: Formation of $\mathrm{HNO}_{2}$ on aerosol surfaces during foggy periods in the presence of $\mathrm{NO}$ and $\mathrm{NO}_{2}$, Atmos. Environ. A-Gen., 26, 211-217, 1992.

Oswald, R., Behrendt, T., Ermel, M., Wu, D., Su, H., Cheng, Y., Breuninger, C., Moravek, A., Mougin, E., Delon, C., Loubet, B., Pommerening-Roeser, A., Soergel, M., Poeschl, U., Hoffmann, T., Andreae, M. O., Meixner, F. X., and Trebs, I.: HONO emissions from soil bacteria as a major source of atmospheric reactive nitrogen, Science, 341, 1233-1235, 2013.

Petersson, A.-S., Steen, H., Kalume, D. E., Caidahl, K., and Roepstorff, P.: Investigation of tyrosine nitration in proteins by mass spectrometry, J. Mass Spectrom., 36, 616-625, https://doi.org/10.1002/jms.161, 2001.

Prutz, W. A.: Tyrosine oxidation by $\mathrm{NO}_{2}$ in aqueous-solution, $\mathrm{Z}$. Naturforsch. C, 39, 725-727, 1984.

Prutz, W. A., Monig, H., Butler, J., and Land, E. J.: Reactions of nitrogen dioxide in aqueous model systems - oxidation of tyrosine units in peptides and proteins, Arch. Biochem. Biophys., 243, 125-134, https://doi.org/10.1016/0003-9861(85)90780-5, 1985.

Pummer, B. G., Budke, C., Augustin-Bauditz, S., Niedermeier, D., Felgitsch, L., Kampf, C. J., Huber, R. G., Liedl, K. R., Loerting, T., Moschen, T., Schauperl, M., Tollinger, M.,
Morris, C. E., Wex, H., Grothe, H., Pöschl, U., Koop, T., and Fröhlich-Nowoisky, J.: Ice nucleation by watersoluble macromolecules, Atmos. Chem. Phys., 15, 4077-4091, https://doi.org/10.5194/acp-15-4077-2015, 2015.

Ramazan, K. A., Syomin, D., and Finlayson-Pitts, B. J.: The photochemical production of $\mathrm{HONO}$ during the heterogeneous hydrolysis of $\mathrm{NO}_{2}$, Phys. Chem. Chem. Phys., 6, 3836-3843, 2004.

Reinmuth-Selzle, K., Ackaert, C., Kampf, C. J., Samonig, M., Shiraiwa, M., Kofler, S., Yang, H., Gadermaier, G., Brandstetter, H., Huber, C. G., Duschl, A., Oostingh, G. J., and Pöschl, U.: Nitration of the Birch Pollen Allergen Bet v 1.0101: Efficiency and site-selectivity of liquid and gaseous nitrating agents, J. Proteome Res., 13, 1570-1577, 2014.

Reisinger, A. R.: Observations of $\mathrm{HNO}_{2}$ in the polluted winter atmosphere: possible heterogeneous production on aerosols, Atmos. Environ., 34, 3865-3874, 2000.

Ren, X., Brune, W. H., Oliger, A., Metcalf, A. R., Simpas, J. B., Shirley, T., Schwab, J. J., Bai, C., Roychowdhury, U., Li, Y., Cai, C., Demerjian, K. L., He, Y., Zhou, X., Gao, H., and Hou, J.: $\mathrm{OH}, \mathrm{HO}_{2}$, and $\mathrm{OH}$ reactivity during the PMTACS-NY Whiteface Mountain 2002 campaign: observations and model comparison, J. Geophys. Res., 111, D10S03, https://doi.org/10.1029/2005JD006126, 2006.

Riediker, M., Koller, T., and Monn, C.: Differences in size selective aerosol sampling for pollen allergen detection using highvolume cascade impactors, Clin. Exp. Allergy, 30, 867-873, https://doi.org/10.1046/j.1365-2222.2000.00792.x, 2000.

Ring, J., Kramer, U., Schafer, T., and Behrendt, H.: Why are allergies increasing?, Curr. Opin. Immunol., 13, 701-708, 2001.

Roehl, C. M., Orlando, J. J., Tyndall, G. S., Shetter, R. E., Vazquez, G. J., Cantrell, C. A., and Calvert, J. G.: Temperature dependence of the quantum yields for the photolysis of $\mathrm{NO}_{2}$ near the dissociation limit, J. Phys. Chem.-US, 98, 7837-7843, https://doi.org/10.1021/j100083a015, 1994.

Salgado, M. S. and Rossi, M. J.: Flame soot generated under controlled combustion conditions: Heterogeneous reaction of $\mathrm{NO}_{2}$ on hexane soot, Int. J. Chem. Kinet., 34, 620-631, https://doi.org/10.1002/kin.10091, 2002.

Selzle, K.; Ackaert, C.; Kampf, C. J., Kunert, A. T., Duschl, A., Oostingh, G. J., and Pöschl, U.: Determination of nitration degrees for the birch pollen allergen Bet v 1, Anal. Bioanal. Chem., 405, 8945-8949, 2013.

Shiraiwa, M., Ammann, M., Koop, T., and Pöschl, U.: Gas uptake and chemical aging of semisolid organic aerosol particles, P. Natl. Acad. Sci. USA, 108, 11003-11008, https://doi.org/10.1073/pnas.1103045108, 2011.

Shiraiwa, M., Selzle, K., Yang, H., Sosedova, Y., Ammann, M., and Poeschl, U.: Multiphase chemical kinetics of the nitration of aerosolized protein by ozone and nitrogen dioxide, Environ. Sci. Technol., 46, 6672-6680, 2012.

Sörgel, M., Regelin, E., Bozem, H., Diesch, J.-M., Drewnick, F., Fischer, H., Harder, H., Held, A., Hosaynali-Beygi, Z., Martinez, M., and Zetzsch, C.: Quantification of the unknown HONO daytime source and its relation to $\mathrm{NO}_{2}$, Atmos. Chem. Phys., 11, 10433-10447, https://doi.org/10.5194/acp-11-104332011, 2011.

Sörgel, M., Trebs, I., Wu, D., and Held, A.: A comparison of measured HONO uptake and release with calculated source strengths 
in a heterogeneous forest environment, Atmos. Chem. Phys., 15, 9237-9251, https://doi.org/10.5194/acp-15-9237-2015, 2015.

Sosedova, Y., Rouviere, A., Bartels-Rausch, T., and Ammann, M.: UVA/Vis-induced nitrous acid formation on polyphenolic films exposed to gaseous $\mathrm{NO}_{2}$, Photochem. Photobiol. Sci., 10, 16801690, 2011.

Stadler, D. and Rossi, M. J.: The reactivity of $\mathrm{NO}_{2}$ and $\mathrm{HONO}$ on flame soot at ambient temperature: the influence of combustion conditions, Phys. Chem. Chem. Phys., 2, 5420-5429, https://doi.org/10.1039/b005680o, 2000.

Staton, S. J. R., Woodward, A., Castillo, J. A., Swing, K., and Hayes, M. A.: Ground level environmental protein concentrations in various ecuadorian environments: potential uses of aerosolized protein for ecological research, Ecol. Indic., 48, 389395, https://doi.org/10.1016/j.ecolind.2014.08.036, 2015.

Stemmler, K., Ammann, M., Donders, C., Kleffmann, J., and George, C.: Photosensitized reduction of nitrogen dioxide on humic acid as a source of nitrous acid, Nature, 440, 195-198, 2006.

Stemmler, K., Ndour, M., Elshorbany, Y., Kleffmann, J., D’Anna, B., George, C., Bohn, B., and Ammann, M.: Light induced conversion of nitrogen dioxide into nitrous acid on submicron humic acid aerosol, Atmos. Chem. Phys., 7, 4237-4248, https://doi.org/10.5194/acp-7-4237-2007, 2007.

Su, H., Cheng, Y. F., Shao, M., Gao, D. F., Yu, Z. Y., Zeng, L. M., Slanina, J., Zhang, Y. H., and Wiedensohler, A.: Nitrous acid (HONO) and its daytime sources at a rural site during the 2004 PRIDE-PRD experiment in China, J. Geophys. Res., 113, D14312, https://doi.org/10.1029/2007JD009060, 2008.

Su, H., Cheng, Y., Oswald, R., Behrendt, T., Trebs, I., Meixner, F. X., Andreae, M. O., Cheng, P., Zhang, Y., and Poeschl, U.: Soil nitrite as a source of atmospheric HONO and $\mathrm{OH}$ radicals, Science, 333, 1616-1618, 2011.

Sumner, A. L., Menke, E. J., Dubowski, Y., Newberg, J. T., Penner, R. M., Hemminger, J. C., Wingen, L. M., Brauers, T., and Finlayson-Pitts, B. J.: The nature of water on surfaces of laboratory systems and implications for heterogeneous chemistry in the troposphere, Phys. Chem. Chem. Phys., 6, 604-613, https://doi.org/10.1039/B308125G, 2004.

Syomin, D. A. and Finlayson-Pitts, B. J.: HONO decomposition on borosilicate glass surfaces: implications for environmental chamber studies and field experiments, Phys. Chem. Chem. Phys., 5, 5236-5242, 2003.

Villena, G., Wiesen, P., Cantrell, C. A., Flocke, F., Fried, A., Hall, S. R., Hornbrook, R. S., Knapp, D., Kosciuch, E., Mauldin, R. L., McGrath, J. A., Montzka, D., Richter, D., Ullmann, K., Walega, J., Weibring, P., Weinheimer, A., Staebler, R. M., Liao, J., Huey, L. G., and Kleffmann, J.: Nitrous acid (HONO) during polar spring in Barrow, Alaska: a net source of OH radicals?, J. Geophys. Res., 116, D00R07, https://doi.org/10.1029/2011JD016643, 2011.
Weber, B., Wu, D., Tamm, A., Ruckteschler, N., RodriguezCaballero, E., Steinkamp, J., Meusel, H., Elbert, W., Behrendt, T., Soergel, M., Cheng, Y., Crutzen, P. J., Su, H., and Poeschi, U.: Biological soil crusts accelerate the nitrogen cycle through large NO and HONO emissions in drylands, P. Natl. Acad. Sci. USA, 112, 15384-15389, 2015.

Wong, K. W., Tsai, C., Lefer, B., Haman, C., Grossberg, N., Brune, W. H., Ren, X., Luke, W., and Stutz, J.: Daytime HONO vertical gradients during SHARP 2009 in Houston, TX, Atmos. Chem. Phys., 12, 635-652, https://doi.org/10.5194/acp-12-6352012, 2012.

Yang, H., Zhang, Y. Y., and Pöschl, U.: Quantification of nitrotyrosine in nitrated proteins, Anal. Bioanal. Chem., 397, 879-886, 2010.

Zhang, Q. and Anastasio, C.: Free and combined amino compounds in atmospheric fine particles $\left(\mathrm{PM}_{2.5}\right)$ and fog waters from Northern California, Atmos. Environ., 37, 2247-2258, 2003.

Zhang, Y. Y., Yang, H., and Pöschl, U.: Analysis of nitrated proteins and tryptic peptides by HPLC-chip-MS/MS: site-specific quantification, nitration degree, and reactivity of tyrosine residues, Anal. Bioanal. Chem., 399, 459-471, 2011.

Zhou, X. L., Beine, H. J., Honrath, R. E., Fuentes, J. D., Simpson, W., Shepson, P. B., and Bottenheim, J. W.: Snowpack photochemical production of HONO: a major source of $\mathrm{OH}$ in the Arctic boundary layer in springtime, Geophys. Res. Lett., 28, 4087-4090, 2001.

Zhou, X. L., Civerolo, K., Dai, H. P., Huang, G., Schwab, J., and Demerjian, K.: Summertime nitrous acid chemistry in the atmospheric boundary layer at a rural site in New York State, J. Geophys. Res., 107, 4590, https://doi.org/10.1029/2001JD001539, 2002.

Zhou, X. L., Gao, H. L., He, Y., Huang, G., Bertman, S. B., Civerolo, K., and Schwab, J.: Nitric acid photolysis on surfaces in low- $\mathrm{NO}_{x}$ environments: significant atmospheric implications, Geophys. Res. Lett., 30, 2217, https://doi.org/10.1029/2003GL018620, 2003. 